\title{
Pharmacokinetic and pharmacodynamic analysis of 5-aza-2'-deoxycytidine (decitabine) in the design of its dose-schedule for cancer therapy
}

\author{
Metin Karahoca ${ }^{1}$ and Richard L Momparler ${ }^{1,2^{*}}$
}

\begin{abstract}
5-Aza-2'-deoxycytidine (5-AZA-CdR, decitabine), an epigenetic drug that inhibits DNA methylation, is currently used to treat myelodysplastic syndrome (MDS), and is under investigation for treating acute myeloid leukemia (AML) and other malignancies. 5-AZA-CdR can reactivate tumor suppressor genes silenced by aberrant DNA methylation, a frequent event in all types of cancer. Because this epigenetic change is reversible, it is a good target for 5-AZA-CdR therapy. We have reviewed the preclinical data of 5-AZA-CdR to analyze the concentrations and exposure times required to eradicate cancer stem cells. We analyzed the dose-schedules used in animal models that show potent antineoplastic activity of 5-AZA-CdR. We attempted to correlate the preclinical data with the responses obtained in clinical trials of 5-AZA-CdR in patients with cancer. The pharmacokinetics and drug distribution of 5-AZA-CdR are key parameters because adequate therapeutic drug levels are required to eliminate cancer stem cells in all anatomic compartments. The plasma half-life of 5-AZA-CdR in humans is approximately 20 minutes due to the high levels in the liver of cytidine deaminase, the enzyme that inactivates this analogue. This provides a rationale to use an inhibitor of cytidine deaminase in combination with 5-AZA-CdR. Low-dose 5-AZA-CdR is effective for MDS and AML and can induce complete remissions (CR). However, maintenance of CR with low-dose 5-AZA-CdR is difficult. Based on analyses of preclinical and clinical data, low dose 5-AZA-CdR has the potential to be an effective form of therapy in some patients with cancer. For patients who do not respond to low dose therapy we recommend dose-intensive treatment with 5-AZA-CdR. Patients who are candidates for intensive dose 5-AZA-CdR should have a good bone marrow status so as to permit adequate recovery from myelosuppression, the major toxicity of 5-AZA-CdR. Solid tumors are also interesting targets for therapy with 5-AZA-CdR. Both low dose and intensive therapy with 5-AZA-CdR can reduce the proliferative potential of tumor stem cells in animal models. We propose novel dose schedules of 5-AZA-CdR for investigation in patients with cancer. The full chemotherapeutic potential of 5-AZA-CdR to treat cancer merits further clinical investigation and can only be realized when its optimal dose-schedule is determined.
\end{abstract}

Keywords: Decitabine, 5-aza-2'-deoxycytidine, Epigenetics, AML, MDS, DNA methylation, Pharmacokinetics, Pharmacodynamics

\section{Introduction}

5-Aza-2'-deoxycytidine (5-AZA-CdR, decitabine) was first synthesized in 1964 by Pliml and Sorm [1] and its potential activity in leukemia was reported in 1968 by Sorm and Vesely [2]. 5-AZA-CdR is an analog of the natural nucleoside 2 -deoxycytidine in which the carbon

\footnotetext{
*Correspondence: richard.I.momparler@umontreal.ca

'Département de Pharmacologie, Université de Montréal, Montréal, Québec, Canada

${ }^{2}$ Service of Hematology and Oncology, Centre de recherche,

CHU-Saint-Justine, 3175 Côte Sainte-Catherine, Montréal, Québec H3T 1C5, Canada
}

(c) 2013 Karahoca and Momparler; licensee BioMed Central Ltd. This is an Open Access article distributed under the terms of the Creative Commons Attribution License (http://creativecommons.org/licenses/by/2.0), which permits unrestricted use, distribution, and reproduction in any medium, provided the original work is properly cited. in the 5-position of the cytosine is replaced by nitrogen. Preclinical studies in rodents indicated that 5-AZA-CdR is a more potent antileukemic agent than cytosine arabinoside (ARA-C) [3,4]. In 1979, Taylor and Jones [5] reported that 5-AZA-CdR could induce cells in culture to differentiate into different phenotypes and this activity correlated with its inhibition of DNA methylation. The first review on the pharmacologic properties of 5-AZA$\mathrm{CdR}$ was published in 1979 [6] and the first clinical trial on 5-AZA-CdR in patients with acute leukemia was published in 1981 [7].

\section{Biomed Central}


Although the unique demethylating capacity of 5-AZACdR has been known for many years, its approval for the treatment of cancer took a long time, perhaps due to a lack of understanding of the importance of epigenetic changes in malignancy during the early years of development [8]. 5-AZA-CdR was approved for the treatment of myelodysplastic syndrome (MDS) in 2006 and shows antileukemic activity against acute myeloid leukemia (AML) as well $[8,9]$. Its clinical activity against solid tumors is under investigation. 5-AZA-CdR also displays some effectiveness in the treatment of sickle cell disease, which is nonmalignant [10]. Low-dose 5-AZA-CdR was proposed to be effective for treating MDS due to its epigenetic action, whereas higher doses were too toxic due the poor hematologic status of these patients [11]. The objectives of this review is to analyze preclinical and clinical data on 5-AZA-CdR and develop a rationale for optimization of its dose schedule for the treatment of cancer.

\section{Review}

\section{Mode of action and cellular metabolism}

Recent progress on elucidating the important role of epigenetics in the development of malignancy has generated more interest in the chemotherapeutic potential of 5-AZA$\mathrm{CdR}$ for the treatment of cancer $[12,13]$. 'Epigenetics' refers to the study of heritable changes in gene expression that occur without changes in the DNA sequences [14]. Epigenetic regulation of gene expression is modulated by changes in DNA methylation, covalent histone modifications, and microRNA [15-17]. Hypermethylated tumor suppressor genes represent one of the most consistent hallmarks of human cancers [12,18]. Loss of the expression of tumor suppressor genes can lead to a loss of regulation of cancer cell growth [19-21].

DNA methylation usually occurs at the 5-position of the cytosine ring within cytosine-phosphate-guanine (CpG) dinucleotide by a transfer of the methyl group from $S$-adenosyl-L-methionine [22]. DNA methyltransferases (DNMTs) catalyze this reaction. The methylation pattern from the parental DNA is copied onto the newly synthesized DNA strand by the maintenance methyltransferase DNMT 1. In embryonic stem cells and tumor cells, methylation of previously unmethylated DNA (de novo methylation) is catalyzed by DNMT 3a or DNMT $3 \mathrm{~b}$ [23]. To inactivate transcription, methylation usually occurs in the CpG islands in the promoter-exon regions of target genes. Half of all genes harbor CpG islands in their promoters [24]. In human DNA, approximately 50\% to $70 \%$ of CpG dinucleotides are methylated [25,26]. During normal embryonic development, cytosine methylation is essential for establishing tissue-specific gene expression, silencing imprinted genes, and inactivating the $\mathrm{X}$ chromosome. Methylation also protects against the transcription of parasitic elements [27].
Both 5-AZA-CdR and 5-azacytidine have been reported to inhibit the expression of the de novo DNA methylating enzymes, DNMT3B [28,29]. DNMT3A-DNMT3B double null embryonic stem cells are highly resistant to 5-AZACdR as compared to single null or wild type cells [30]. Mutations in DNMT3A have been identified in AML and MDS [31,32]. These DNMT3A mutations are associated with a poor outcome for both AML and MDS patients. A recent report showed that DNMT3A plays a role in silencing self-renewal genes in hematopoietic stem cells so as to permit hematopoietic differentiation [33]. Preliminary data indicate that AML patients with low DNMT3A activity may benefit from treatment with 5-AZA-CdR [34]. The full role of DNMT3A and DNMT3B in leukemogenesis still remains to be clarified.

5-AZA-CdR is a prodrug that must be activated by phosphorylation. The metabolism of this analog is summarized in Figure 1. Due to the function of the nucleoside transport system, 5-AZA-CdR rapidly reaches its equilibration state between the extracellular and intracellular compartments, as indicated by the short alpha half-life of five minutes [35].

The cellular uptake of the drug is realized by an equilibrative nucleoside-specific transport mechanism [36-39], which is followed by phosphorylation and incorporation of the drug into DNA, resulting in potent inhibition of DNMT.

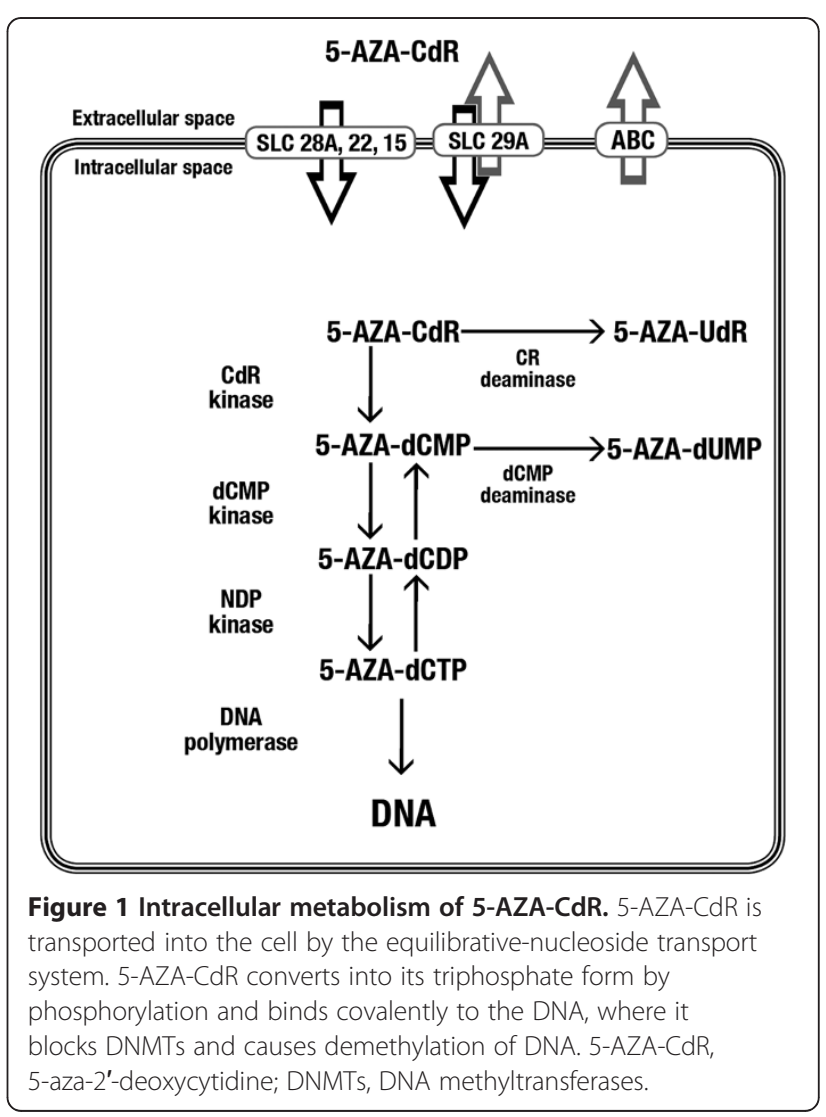


Since $5-A Z A-C d R$ is a prodrug it must be activated by deoxycytidine kinase to its monophosphate form and by other kinases to its triphosphate form, which is then incorporated into DNA by DNA polymerase [5,40-43]. The inhibition of DNA methylation is due to formation of a covalent complex between 5-AZA-CdR-DNA and DNMT1 at $\mathrm{CpG}$ methylation sites, resulting in the inactivation of this enzyme $[44,45]$. DNMT1 inhibition results in DNA hypomethylation, gene activation and the induction of cellular differentiation, senescence, and/or apoptosis [40-42].

5-AZA-CdR does not block the progression of G1phase cells into S-phase [46]. Flow cytometry investigations revealed that 5 -AZA-CdR slows the progression of cells into S-phase, but it does not block cell progression through their cycle [47], unlike the related nucleoside analogs 5-azacytidine and ARA-C [48]. One of the key biochemical markers of $5-\mathrm{AZA}-\mathrm{CdR}$ is the p15 tumor suppressor gene, which is frequently hypermethylated in MDS and AML patients and can be reactivated by this analog [49]. Table 1 summarizes key genes that are silenced by DNA methylation in different types of cancer as published in the review by Esteller [15].

\section{In vitro antineoplastic action}

\section{Leukemia}

In vitro studies of 5 -AZA-CdR demonstrate that it induces differentiation, apoptosis, and senescence in leukemic cells [40-42,50-52]. One proposed mechanism of this action is that 5 -AZA-CdR exposure reduces the expression of $\mathrm{c}$-myc, an oncogene that prevents the terminal differentiation of cells [53]. 5-AZA-CdR also maintains hematopoietic precursor self-renewal [54]. Leukemic cells can undergo phenotypic modification after exposure to 5-AZA-CdR, as indicated by the increased expression of several antigen markers [55,56]. 5-AZA-CdR enhances the graft-versus leukemia effect, which has the potential to

Table 1 Silencing by DNA methylation of key genes in different types of cancer $^{a}$

\begin{tabular}{ll}
\hline Genes & Type of cancer \\
\hline p16, p14, RARß2, SFRP1 & Colon cancer \\
\hline p16, p14 & Esophageal cancer \\
\hline p14, hMLH1 & Stomach cancer \\
\hline SOCS1, GSTP1 & Liver cancer \\
\hline ER, BRCA1, E-cadherin, TMS1 & Breast cancer \\
\hline BRCA1 & Ovarian cancer \\
\hline GSTP1 & Prostate cancer \\
\hline p16, DAPK, RASSFIA & Lung cancer \\
\hline p16, TPEF/HPP1, miR-127 & Bladder cancer \\
\hline VHL & Kidney cancer \\
\hline p15, EST1, ID4 & Leukemia \\
\hline p16, p73, MGMT & Lymphoma \\
\hline amodified from Esteller M. [15]. p16, p16 ${ }^{\text {INK4a } ; p 14, ~ p 14 ~}$ & $;$ p15, p15 ${ }^{\text {AnK4b }}$.
\end{tabular}

increase the immunologic therapeutic efficacy of allogeneic transplantation [57]. 5-AZA-CdR also induces the upregulation of DNA repair genes and angiogenesis inhibitor genes [58]. These changes can suppress the development of malignancy. In vitro studies of 5-AZA-CdR also illustrate its potent antileukemic activity $[59,60]$. At equimolar concentrations, 5-AZA-CdR more potently reduces colony formation than either 5-azacytidine or ARA-C [61]. 5-AZA-CdR also has greater DNA-hypomethylating activity than 5-azacytidine [61]. In vitro studies on the induction of the loss of clonogenicity by 5 -AZA-CdR on human leukemic cell lines of different phenotypes are summarized in Table 2. The 50\% inhibitory concentration (IC50) of colony formation for a one-hour exposure to 5-AZA-CdR was approximately $10 \mu \mathrm{M}$ for HL-60 (myeloid), Molt-3 (T-cell) and RPMI-8392 (B-cell) leukemic cell lines. For a 24-hour exposure, the IC50 of 5-AZA-CdR is in the range of $0.1 \mu \mathrm{M}$ for these leukemic cell lines. This observation illustrates the importance of the duration of treatment with respect to the antileukemic activity of 5-AZA-CdR.

\section{In solid tumors}

Several studies on different type of tumors demonstrated an association between DNA hypermethylation and DNMT overexpression [62-64]. The precise molecular mechanism of aberrant DNA methylation, however, remains to be clarified. The first tumor suppressor gene found to undergo silencing as a result of promoter methylation was the $\mathrm{Rb}$ gene in retinoblastoma tumors, followed by numerous other tumor suppressor genes [65-67]. 5-AZA-CdR reactivates many genes that suppress malignancy and are silenced by aberrant DNA methylation in solid tumors (Table 1 ). 5-AZA-CdR reactivates the tumor suppressor gene VHL in human renal carcinoma cell lines and the expression of the p16/ CDKN2 tumor suppressor gene, which prevents the entry of tumor cells into the S-phase of the cell cycle, in different tumor cell lines [20,68-72]. The mRNA expression of the p53 gene increases in hepatoma cell lines after

Table 2 In vitro concentrations of 5-AZA-CdR that eradicate the proliferative potential of leukemic cells

\begin{tabular}{llll}
\hline Leukemic cell lines & IC50 & $\begin{array}{l}\text { Duration of } \\
\text { exposure }\end{array}$ & References \\
\hline HL 60 (myeloid) & $100 \mu \mathrm{M}$ & 1 hour & {$[59]$} \\
\hline Molt-3 (T-cell) & $10 \mu \mathrm{M}$ & 1 hour & {$[59]$} \\
\hline RPMI 8392 (B-cell) & $10 \mu \mathrm{M}$ & 1 hour & {$[59]$} \\
\hline HL60 leukemic cells & 0.05 to $0.1 \mu \mathrm{M}$ & 24 hours & {$[60]$} \\
\hline L1210 leukemic cells & $0.075 \mu \mathrm{M}$ & 18 hours & {$[60]$} \\
\hline Molt-3 (T-cell) & about $0.1 \mu \mathrm{M}$ & 24 hours & {$[59]$} \\
\hline HL 60 (myeloid) & about $0.1 \mu \mathrm{M}$ & 24 hours & {$[59]$} \\
\hline RPMI 8392 (B-cell) & about $0.1 \mu \mathrm{M}$ & 24 hours & {$[59]$} \\
\hline
\end{tabular}

$1 \mu \mathrm{M}=228 \mathrm{ng} / \mathrm{ml}$. 5-AZA-CdR, 5-Aza-2'-deoxycytidine; IC50, half maximal inhibitory concentration. 
treatment with 5-AZA-CdR [73]. Methylation of hMLH1, a mismatch repair gene that confers chemoresistance to certain anticancer agents, is reactivated by 5 -AZA-CdR in ovarian and colon cancer cell lines [74,75]. 5-AZA-CdR reactivates CDKN2a (p16INK4a) in lung cancer, BRCA1 in breast cancer, and MGMT in glioblastomas [76-79]. Expression of unmethylated genes, such as Apaf-1 and CDKN2D in malignant melanoma and lung cancer, is enhanced after 5-AZA-CdR treatment, indicating that gene activation can occur by indirect mechanisms [80,81]. 5-AZA-CdR reduces natural killer cell responsiveness, which may be used in therapeutic strategies to target malignant cells by an immune mechanism [82].

Preclinical studies using colony assays indicate that 5 -AZA-CdR is an active antineoplastic agent against many different tumor cell lines [60,83-88]. These studies demonstrated that the demethylation of genes involved in cell cycle control inhibits the growth of various tumors $[66,79,89]$. The in vitro studies on the antineoplastic activity of 5-AZA-CdR in tumor cell lines are summarized in Table 3. For example, the IC50 is approximately $4 \mu \mathrm{M}$ for a two-hour exposure in fibrosarcoma cells and approximately $0.5 \mu \mathrm{M}$ for a four-hour exposure in Calu-6 lung carcinoma cells $[60,88]$. For a 48-hour exposure, the IC50 is in the range of $0.1 \mu \mathrm{M}$ for different tumor cell lines (Table 3 ). As observed with leukemic cells, the duration of treatment is a key factor with respect to the antineoplastic activity of 5-AZA-CdR.

\section{In vivo antineoplastic action}

The antineoplastic activity of 5-AZA-CdR was first demonstrated in mouse models of acute leukemia [2]. In

Table 3 In-vitro concentrations of 5-AZA-CdR that eradicate proliferative potential of solid tumor cells

\begin{tabular}{|c|c|c|c|}
\hline Tumor cell lines & IC 50 & $\begin{array}{l}\text { Duration of } \\
\text { treatment }\end{array}$ & References \\
\hline HS-SY-II synovial sarcoma & $1.3 \mu \mathrm{M}$ & 96 hours & {$[84]$} \\
\hline SYO-1 synovial sarcoma & $0.9 \mu \mathrm{M}$ & 96 hours & [84] \\
\hline KB oropharyngeal cancer & $0.5 \mu \mathrm{M}$ & 96 hours & {$[85]$} \\
\hline A549 lung adenocancer & $0.49 \mu \mathrm{M}$ & 96 hours & {$[85]$} \\
\hline LoVo colon cancer & $0.4 \mu \mathrm{M}$ & 96 hours & {$[85]$} \\
\hline LoVo-DX colon cancer & $0.1 \mu \mathrm{M}$ & 96 hours & {$[85]$} \\
\hline MDA-MB- 435 breast cancer & $0.2 \mu \mathrm{M}$ & 48 hours & {$[83]$} \\
\hline Hs578T breast cancer & $0.13 \mu \mathrm{M}$ & 48 hours & {$[87]$} \\
\hline MCF-7 breast cancer & $0.13 \mu \mathrm{M}$ & 48 hours & {$[87]$} \\
\hline MDA-MB- 231 breast cancer & $0.013 \mu \mathrm{M}$ & 48 hours & {$[83]$} \\
\hline EMT6 mammary cancer & $0.22 \mu \mathrm{M}$ & 18 hours & {$[60]$} \\
\hline Calu-6 lung cancer & $0.44 \mu \mathrm{M}$ & 4-8 hours & {$[60]$} \\
\hline $\mathrm{A}(\mathrm{T} 1) \mathrm{C} 1-3$ fibrosarcoma & $4.38 \mu \mathrm{M}$ & 2 hours & [88] \\
\hline
\end{tabular}

$1 \mu \mathrm{M}=228 \mathrm{ng} / \mathrm{ml}$. 5-AZA-CdR, 5-Aza-2'-deoxycytidine; IC50, half maximal inhibitory concentration. mice with murine L1210 leukemia, the activity of 5-AZACDR markedly increases with an increased dose and exposure time $[60,61]$. In a preclinical study using the L1210 mouse leukemia model, the curative dose of 5-AZA-CdR administered as a 15-hour infusion was $20 \mathrm{mg} / \mathrm{kg}$. The antileukemic activity of 5-AZA-CdR, 5-azacytidine, and ARA-C was compared in the L1210 leukemia mouse model [61]. The mice were administered these nucleoside analogs in a 15-hour continuous intravenous (i.v.) infusion to obtain an effective plasma concentration of the drug that persisted longer than the cell cycle of these leukemia cells (12 hours). At equitoxic doses, 5-azacytidine (11.7 $\mathrm{mg} / \mathrm{kg}$ ) increased the life span of the mice by $63 \%$, whereas 5-AZA-CdR $(10.1 \mathrm{mg} / \mathrm{kg})$ increased the life span of the mice by $384 \%$. At higher doses, 5-AZA-CdR cured the mice of leukemia, but 5-azacytidine or ARA-C did not. Because the cell cycle of L1210 leukemic cells is around 12 hours in duration, the 15-hour infusion of these analogs was predicted to produce $100 \%$ cell kill in this mouse model because all of the leukemic cells entered S-phase during the treatment. Analysis of the surviving leukemic cells revealed that they were not resistant to ARA-C.

In a rat model of myeloid leukemia, 5-AZA-CdR increased survival in a dose-related manner [4]. In this model, the antileukemic action of 5-AZA-CdR exceeded that of ARA-C. The hematologic toxicity of 5-AZA-CdR was evaluated in this rat model by the colony forming unit in the spleen (CFU-S) assay [4]. The maximum number of hematopoietic stem cells killed at high doses of 5-AZA$\mathrm{CdR}$ was the same as that at low doses, indicating that the response reaches a plateau upon dose escalation. This is solid evidence that normal resting hematopoietic stem cells survive high-dose treatment with 5-AZA-CdR. The difference between hematopoietic stem cell toxicity and antileukemic effects favors treatment with high doses of 5-AZA-CdR because the dose that causes maximal leukemic cell kill is not more toxic to resting hematopoietic stem cells.

5-AZA-CdR displays significant antineoplastic activity against tumors in a mouse model. In mice bearing EMT6 mammary tumors, 5-AZA-CdR at a dose of $15 \mathrm{mg} / \mathrm{kg}$ produces a 2-log reduction in clonogenic survival as measured by excision of the tumor, preparation of a single-cell suspension and analysis of survival by in vitro colony formation [60]. A higher dose of $30 \mathrm{mg} / \mathrm{kg}$ produces a 3-log reduction in clonogenic survival. These observations illustrate the effectiveness of intensive doses of 5-AZA-CdR for tumor therapy.

\section{Pharmacokinetics of 5-AZA-CdR}

Methods used to determine concentrations of 5-Aza-CdR Several methods are used to determine 5-AZA-CdR concentrations, including bioassays, HPLC, and HPLC 
combined with mass spectrometry (HPLC/MS). Among these methods, HPLC/MS is the most sensitive followed by bioassays; both of these methods are superior to HPLC alone for detecting low concentrations of 5-AZA-CdR. The lower limit of detection of 5-AZA-CdR is in the range of $0.01 \mu \mathrm{M}$. For pharmacokinetic studies, HPLC/MS is the method of choice for detecting the plasma concentration of 5-AZA-CdR followed by the bioassay and HPLC methods (Table 4) [7,36,90-92].

\section{Pharmacokinetic data}

The moderate chemical instability of 5 -AZA-CdR is important and dependent on both temperature and $\mathrm{pH}$ [93]. Therefore, this agent must be carefully formulated. The instability is due to the opening of the 5-azacytosine ring between positions 5 and 6 to form $N$-(formylamidino)$N^{\prime}-\beta$-D-2-deoxyribofuranosylurea (NFDU). This reaction is highly reversible in favor of 5-AZA-CdR and results in a minimal loss of pharmacologic activity. When NFDU decomposes irreversibly via loss of the formyl moiety to form $N^{\prime}$ - $\beta$-D-2-deoxyribofuranosyl-3-guanylurea (DGU), there is a complete loss of pharmacologic activity. This reaction occurs rapidly in alkaline solutions and increases with elevation of the temperature. At $24^{\circ} \mathrm{C}$, the $50 \%$ decomposition rates (D50s) of 5-AZA-CdR to DGU at $\mathrm{pH}$ 7.0 and 8.5 are 22 hours and 5 hours, respectively. At $37^{\circ} \mathrm{C}$, the D50s at $\mathrm{pH} 7.0$ and 8.5 are 12 hours and 2 hours, respectively. At $5^{\circ} \mathrm{C}$ and $\mathrm{pH} 7.0$ to 7.4 , the decomposition of 5-AZA-CdR to DGU is minimal $(<1 \%)$. To formulate 5-AZA-CdR, we recommend using 5 to10 $\mathrm{mM}$ potassium phosphate, $\mathrm{pH} 7.0$ to 7.4 and storage at $5^{\circ} \mathrm{C}$ until clinical use. A fresh solution of $5-\mathrm{AZA}-\mathrm{CdR}$ can be prepared every eight hours. During the infusion of 5-AZA-CdR to patients, we recommend using an ice pack to maintain the temperature at $10^{\circ} \mathrm{C}$ [93]. After i.v. administration of 5-AZA-CdR, its binding to plasma protein is less than $1 \%$. There is a rapid distribution of 5-AZA-CdR between the extra- and intracellular compartments after i.v. injection, as indicated by its alpha half-life of five minutes [35].

5-AZA-CdR penetrates the blood-brain barrier. The level of 5-AZA-CdR in the cerebrospinal fluid (CSF) reaches as high as $50 \%$ of its plasma level during a continuous infusion

Table 4 Comparison of methods to determine concentration of 5-AZA-CdR

\begin{tabular}{lll}
\hline Method & Limit sensitivity for detection & References \\
\hline Bioassay & $5 \mathrm{nM}$ & {$[7]$} \\
\cline { 2 - 3 } & $6 \mathrm{nM}$ & {$[36]$} \\
\hline HPLC & $750 \mathrm{nM}$ & {$[90]$} \\
\hline HPLC/MS & $10 \mathrm{nM}$ & {$[91]$} \\
\cline { 2 - 3 } & $5 \mathrm{nM}$ & {$[92]$} \\
\hline
\end{tabular}

$1 \mu \mathrm{M}=228 \mathrm{ng} / \mathrm{ml}$. 5-AZA-CdR, 5-Aza-2'-deoxycytidine; HPLC, high performance liquid chromatography; HPLC/MS, Hjgh performance liquid chromatography/mass spectrometry.
[35]. The beta plasma half-life of 5-AZA-CdR in adults is approximately 15 to 25 minutes due to very high levels of cytidine deaminase in the human liver and spleen [94,95] In pediatric populations, the beta half-life is 10 to $15 \mathrm{~min}$ utes, which is shorter than that of adults, probably due to the higher cytidine deaminase activity in the liver and spleen of children [7,90]. Repeated administration of 5-AZA-CdR in patients with MDS as a 3-hour infusion of $15 \mathrm{mg} / \mathrm{m}^{2}$ every eight hours for three days does not result in systemic accumulation of the drug, and the pharmacokinetic parameters remain unchanged from cycle to cycle [92]. An illustration of the plasma pharmacokinetics of the dose schedule that is currently used to treat MDS and AML is shown in Figure 2. 5-AZA-CdR is cleared from the systemic circulation rapidly. $5-\mathrm{AZA}-\mathrm{CdR}$ is inactivated primarily through deamination by cytidine deaminase in the human liver and spleen [94,95]. The half-life of 5-AZA-CdR is related to the blood flow into the liver. Its clearance exceeds the total renal capacity, which suggests an important role of non-renal elimination. The clearance rate has been reported as approximately $125 \pm 20 \mathrm{ml} / \mathrm{min} /$ $\mathrm{kg}$ [36]. The urinary excretion of unchanged 5-AZA-CdR is low, typically $<1 \%$ of the total dose given to the patients [36]. Oral formulations of 5-AZA-CdR are currently under investigation [96]. The pharmacokinetic parameters of 5-AZA-CdR are summarized in Table 5.

\section{5-Aza-CdR in the treatment of hematologic malignancies}

5-AZA-CdR was first used as a single agent in a phase I study in children with relapsed or refractory acute

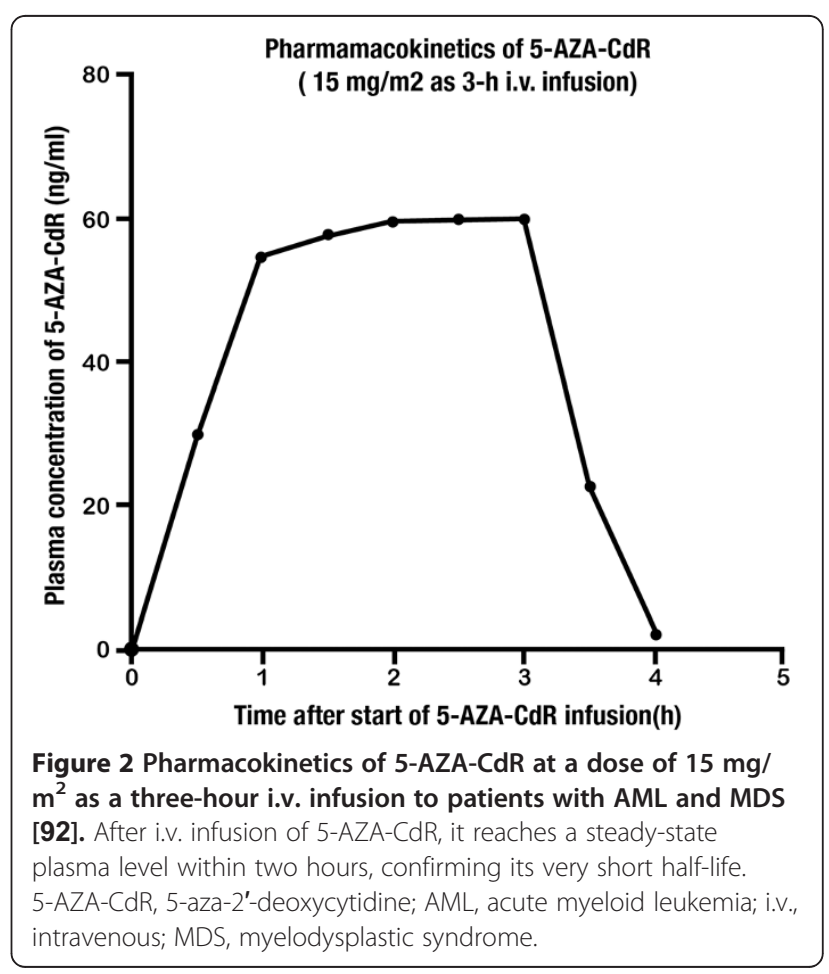


Table 5 Clinical studies on pharmacokinetics of 5-AzaCdR

\begin{tabular}{llll}
\hline $\begin{array}{l}\text { Method } \\
\text { (reference) }\end{array}$ & Dose-schedule & $\begin{array}{l}\text { Plasma } \boldsymbol{\beta} \text { half- } \\
\text { life (minutes) }\end{array}$ & $\begin{array}{l}\text { Clearance } \\
\text { (ml/min/kg) }\end{array}$ \\
\hline Bioassay[36] & $\begin{array}{l}25 \text { to } 100 \mathrm{mg} / \mathrm{m}^{2} 1 \\
\text { hour inf q8 hours }\end{array}$ & $35+/-5$ & $126+/-21$ \\
\hline LCMS[92] & $\begin{array}{l}15 \mathrm{mg} / \mathrm{m}^{2} \text { 3hour inf } \\
\text { q8 hours }\end{array}$ & 35 & $127-135$ \\
\hline HPLC[90] & $\begin{array}{l}30 \mathrm{mg} / \mathrm{m}^{2} 40 \text { to } 60 \\
\text { hours inf }\end{array}$ & 10 to 15 & - \\
\hline
\end{tabular}

5-AZA-CdR, 5-aza-2-deoxycytidine; inf, infusion; LCMS, liquid chromatography/mass spectrometry.

leukemia [7]. Escalating doses of 5-AZA-CdR between 0.75 and $80 \mathrm{mg} / \mathrm{kg}$ were explored. When 5-AZA-CdR was given at doses of 1 to $25 \mathrm{mg} / \mathrm{m}^{2} /$ hour for 12 to 30 hours, only minor responses were observed. At a dose of 25 to $50 \mathrm{mg} /$ $\mathrm{m}^{2} /$ hour for 36 to 44 hours (2.35 to $\left.4.70 \mu \mathrm{M}\right)$, two complete remissions (CRs) were observed among nine patients. The authors reported a significant reduction of circulating blasts at all dose levels. In addition, 5-AZA-CdR cleared the CSF of two acute lymphocytic leukemia (ALL) patients with central nervous system involvement. No maximum tolerated dose (MTD) was reported. The major toxicity was myelosuppression that occurred at doses of 36 to $80 \mathrm{mg} / \mathrm{kg}$ infused over 36 to 44 hours. In a continuation of this study, 27 pediatric acute leukemia patients were treated with a continuous infusion of 5-AZA-CdR at doses ranging from 37 to $80 \mathrm{mg} / \mathrm{kg}$ over 36 to 60 hours. The predicted steady-state plasma level of 5-AZA-CdR for this schedule is 1.5 to $5 \mu \mathrm{M}$. The overall objective response rate was $37 \%$ (33\% in ALL patients and 50\% in AML patients) [97]. In this phase I trial, the MTD was estimated to be in the range of 1,500 to $2,250 \mathrm{mg} / \mathrm{m}^{2}$ [7,97]. Despite promising outcomes, the development of the drug was discontinued due to the risk of prolonged myelosuppression in patients with advanced leukemia [98].

Several clinical trials investigating different drug dosing schedules of 5-AZA-CdR demonstrated significant clinical benefits in the treatment of patients with MDS and AML [11,56,98-100]. 5-AZA-CdR was initially investigated in a trial of 10 MDS patients [101]. Patients were treated with 5 -AZA-CdR at a daily dose of $45 \mathrm{mg} / \mathrm{m}^{2}$ divided into three four-hour infusions for three days (six patients) or as a continuous infusion of $50 \mathrm{mg} / \mathrm{m}^{2}$ for three days (four patients). 5-AZA-CdR induced an overall response rate of $50 \%$ with a complete hematologic response in $40 \%$ of patients. A subsequent clinical trial reported similar response rates [102]. The finding that low doses of 5-AZA$\mathrm{CdR}(3 \mathrm{mg} / \mathrm{kg} / \mathrm{cycle})$ showed activity in patients with sickle cell anemia, by re-expressing the fetal globin gene [10], led to the suggestion that low-dose use of 5-AZA$\mathrm{CdR}$ could be effective against this disease, as well as MDS $[18,103]$. This hypothesis was evaluated in a phase I study with various low-dose levels of 5-AZA-CdR in patients with MDS or leukemia [11]. Unlike traditional phase I studies, the goal of this study was not to determine the MTD, but to determine the optimal biologic dose of this drug based on the response and other related parameters. Forty-eight patients were enrolled, the majority with AML. Responses were observed at the intermediate dose level of $15 \mathrm{mg} / \mathrm{m}^{2}$ daily $\times 10$ days $\left(150 \mathrm{mg} / \mathrm{m}^{2} /\right.$ course $)$. As a result, this dose level was investigated in 11 additional patients. Of the nine responders, eight achieved CR after one cycle of 5-AZA-CdR. Hematologic toxicities were common but difficult to distinguish from the underlying disease. Non-hematologic side effects were uncommon. Pharmacodynamic studies revealed that dose-dependent decreases in DNA methylation reached a plateau at approximately 150 to $200 \mathrm{mg} / \mathrm{m}^{2} /$ course [104]. Hypomethylation was observed for the p15 tumor-suppressor gene, but there was no clear correlation between hypomethylation of this gene and the overall response [104]. These results suggested that response to 5-AZA-CdR can occur at levels below the MTD and that prolonged exposure increases the response.

5-AZA-CdR was approved by the Food and Drug Administration (FDA) in 2006 for the treatment of MDS on the basis of a phase III multicenter trial [105]. In this trial, 170 patients with MDS were randomized to receive either i.v. $5-\mathrm{AZA}-\mathrm{CdR} 15 \mathrm{mg} / \mathrm{m}^{2}$ over three hours every eight hours for three consecutive days $\left(135 \mathrm{mg} / \mathrm{m}^{2} /\right.$ course) every six weeks or the best supportive care (BSC). The overall response rate for the 5-AZACdR arm was $30 \%$, compared with $7 \%$ for the BSC arm $(P<0.001)$. The median duration of the response was 41 weeks with no difference in the time to AML progression compared with the BSC [105]. Similarly, the European Organization for Research and Treatment of Cancer and the German MDS Study Group conducted a large phase III multicenter trial that randomized 233 elderly patients with higher-risk MDS to receive either i.v. 5-AZA-CdR $15 \mathrm{mg} / \mathrm{m}^{2}$ over three hours every eight hours for three consecutive days $\left(135 \mathrm{mg} / \mathrm{m}^{2} /\right.$ course) every six weeks or the BSC [106]. This trial reported a 34\% overall response rate with 5-AZA-CdR and an improvement in the progressionfree survival $(0.55$ versus 0.25 years; $P=0.004)$ compared with the findings for the BSC group.

The time to AML progression and overall survival, however, did not differ significantly between the two groups. The main adverse effect due to 5-AZA-CdR treatment appears to be myelosuppression, including severe neutropenia, thrombocytopenia, and anemia. The incidence of myelosuppression, however, decreases in responding patients with the continuation of therapy. Grade 3/4 non-hematologic toxicity is rare and usually clinically insignificant.

MDS patients who fail 5-azacytidine treatment can respond to 5-AZA-CdR. In a study of 14 MDS patients 
after the failure of previously administered 5 -azacytidine therapy, low-dose 5 -AZA-CdR $\left(20 \mathrm{mg} / \mathrm{m}^{2} /\right.$ day i.v. over 5 days) was investigated [107]. The overall response rate was $28 \%$ (four patients), including CRs in three patients.

In another study, the activity of 5-AZA-CdR was tested in 27 elderly patients with AML, MDS, or CML [108]. One CR was observed with the dose of $500 \mathrm{mg} /$ $\mathrm{m}^{2} / 24$ hours for the three-day schedule (estimated plasma drug concentration, $2 \mu \mathrm{M}$ ). There were five partial remissions. In this mostly ARA-C-resistant patient group, the efficacy of 5-AZA-CdR was unquestionable. Myelosuppression, however, was prolonged up to 42 days. At the time of this study, G-CSF injections were not available to accelerate bone marrow recovery.

In another study, the activity of 5-AZA-CdR was tested in 27 elderly patients with AML, MDS, or chronic myeloid leukemia (CML) [56]. 5-AZA-CdR was administered at doses of 30 to $90 \mathrm{mg} / \mathrm{m}^{2}$ for AML patients as a four-hour i.v. infusion three times a day for three days. The overall response rate of $45 \%$ was encouraging in this group of patients with refractory disease. On the basis of these promising outcomes, the same research group tested 5-AZA-CdR at higher doses in a cohort of 12 patients with AML [109]. The overall response rate was around $40 \%$ in this group of patients with poor prognoses. The promising results achieved in these two studies support the rationale for further investigations of 5AZA-CdR in AML patients.

In a study of elderly AML patients, 5 -AZA-CdR was administered at $20 \mathrm{mg} / \mathrm{m}^{2} /$ day for five days every four weeks [110]. The overall response rate was around $26 \%$. The median time to response was three cycles. Toxicities were similar to those in the previous studies at this dose level. In the study that led to the approval of 5-AZACdR for MDS by the FDA, a retrospective detailed investigation of bone marrow revealed that 12 patients with AML were misdiagnosed as MDS. Nine of these patients were randomly assigned to receive 5-AZA-CdR, and the response rate in this subgroup for 5 -AZA-CdR was $56 \%$ [105]. Several studies have evaluated the combination of 5-AZA-CdR with other anti-cancer agents [111]. In this review, we have focused primarily on 5-AZA-CdR monotherapy.

Currently, there is no established care for AML patients who are not eligible to receive standard induction chemotherapy due to poor performance status. A phase III study that enrolled 485 patients who were at least 65 years of age with newly diagnosed, de novo, or secondary AML and intermediate or unfavorable risk cytogenetics was performed [112]. 5-AZA-CdR was given at a dose of $20 \mathrm{mg} / \mathrm{m}^{2} /$ day as a one-hour infusion for five consecutive days every four weeks (estimated drug plasma concentration of $2 \mu \mathrm{M}$ for one hour). Patients on 5-AZA-CdR had a median overall survival
(OS) of 7.7 months, compared with 5 months in the control arm with a hazard ratio of 0.85 . The stratified log-rank analysis, however, did not demonstrate a statistical significance between the groups. Subsequently, an unplanned OS analysis with one year of additional follow-up demonstrated the same improvement in median OS with a nominal $P$ value of 0.037 (data on file). As of February 2012, the FDA concluded, based on statistical analysis, that 5-AZA-CdR does not appear to improve survival in older patients with AML [113]. The correlation of clinical responses and plasma levels of 5AZA-CdR in hematologic malignancies and in MDS is summarized in Tables 6 and 7, respectively.

\section{5-Aza-CdR in the treatment of solid tumors}

The anticancer activity of 5-AZA-CdR was studied in patients with refractory and metastatic solid tumors. In a phase I study of 5-AZA-CdR, the efficacy and toxicity of the drug were also explored in three children with metastatic solid tumor [7]. 5-AZA-CdR was given by continuous infusion. At doses in the range of 0.75 to 80 $\mathrm{mg} / \mathrm{kg}$ for 12 to 44 hours, only limited activity was observed.

In a study of refractory metastatic prostate cancer patients, treatment with one-hour infusions of $75 \mathrm{mg} /$ $\mathrm{m}^{2}$ 5-AZA-CdR, every eight hours for three doses stabilized the disease in 2 of 12 patients with an evaluable responses [114]. In another study, a seven-day continuous infusion of 5-AZA-CdR was investigated in patients with refractory solid tumors at a daily dose of $2 \mathrm{mg} / \mathrm{m}^{2}$ [115]. The findings of this study demonstrated that genomic DNA methylation reverted to baseline levels by 28 to 35 days after the start of 5-AZA-CdR treatment. No objective responses were observed, however, probably due to the very low concentrations of 5-AZA-CdR in the body fluids. Only one patient with metastatic ovarian cancer and one patient with renal carcinoma had stable disease.

In a pilot phase I/II study performed in 15 patients with stage III/IV metastatic non-small cell lung cancer (NSCLC), 5-AZA-CdR was administered over eight hours as a continuous infusion at doses of 200 to 660 $\mathrm{mg} / \mathrm{m}^{2}$ [116]. The steady-state plasma level of 5-AZA$\mathrm{CdR}$ was estimated to range from 1 to $5 \mu \mathrm{M}$. Three patients survived beyond 15 months, indicating that relatively high doses of 5-AZA-CdR had anti-tumor activity. One patient who received five cycles of 5-AZA$\mathrm{CdR}$ survived for seven years. The hematopoietic toxicity of this schedule was acceptable. These interesting results warrant further investigation of 5-AZA-CdR for the treatment of NSCLC using longer durations of infusions (18 to 24 hours).

In summary, treatment of solid tumors with 5-AZA$\mathrm{CdR}$ led to only limited responses. Notably, however, the 
Table 6 Correlation of clinical responses and plasma concentrations of 5-AZA-CdR in patients with hematological malignancies

\begin{tabular}{|c|c|c|c|c|c|c|}
\hline $\begin{array}{l}\text { Type of } \\
\text { leukemia }\end{array}$ & Dose-schedule & $\begin{array}{l}\text { Duration } \\
\text { infusion }\end{array}$ & $\begin{array}{l}\text { Estimated plasma } \\
\text { concentration }\end{array}$ & $\begin{array}{l}\text { Estimated AUC } \\
(\mu \mathrm{M} \times \text { hour })\end{array}$ & $\begin{array}{l}\text { Response \%ORR } \\
\text { (\%CR) }\end{array}$ & References \\
\hline$\overline{\mathrm{AML}^{\mathrm{a}}}$ & ind: $135 \mathrm{mg} / \mathrm{m}^{2}$ main: $20 \mathrm{mg} / \mathrm{m}^{2}$ & 1 to 72 hours & 0.12 to $1.25 \mu \mathrm{M}$ & 0.12 to 90 & 26 & [143] \\
\hline AML & $20 \mathrm{mg} / \mathrm{m}^{2}$ & 1 hour & $1.25 \mu \mathrm{M}$ & 1.25 & $25(24)$ & [110] \\
\hline AML & $20 \mathrm{mg} / \mathrm{m}^{2}$ & 1 hour & $1.25 \mu \mathrm{M}$ & 1.25 & $64(47)$ & [144] \\
\hline CMML & $15 \mathrm{mg} / \mathrm{m}^{2}$ & 3 to 4 hours & 0.24 to $0.31 \mu \mathrm{M}$ & 0.72 to 1.24 & 25(11) & {$[105,145,146]$} \\
\hline AML & $20 \mathrm{mg} / \mathrm{m}^{2}$ & 1 hour & $1.25 \mu \mathrm{M}$ & 1.25 & $67(26)$ & [147] \\
\hline$C M L$ & 50 to $100 \mathrm{mg} / \mathrm{m}^{2}$ & 6 hour & 0.52 to $1.0 \mu \mathrm{M}$ & 3.12 to 6.0 & $\begin{array}{l}\text { B28(10),A55(23), } \\
\text { C63(13) }\end{array}$ & [148] \\
\hline CML & 50 to $100 \mathrm{mg} / \mathrm{m}^{2}$ & 6 hours & 0.52 to $1.0 \mu \mathrm{M}$ & 3.12 to 6.0 & $53(0)$ & {$[121,122]$} \\
\hline $\mathrm{CML}$ & 50 to $100 \mathrm{mg} / \mathrm{m}^{2}$ & 6 hours & 0,52 to $1,0 \mu \mathrm{M}$ & 3.12 to 6.0 & $84(10)$ & {$[121,122]$} \\
\hline $\mathrm{AML}^{\mathrm{b}}$ & $90 \mathrm{mg} / \mathrm{m}^{2}$ & 4 hours & $1.41 \mu \mathrm{M}$ & 5.64 & $100(100)$ & [149] \\
\hline $\mathrm{AML}^{\mathrm{C}}$ & 125 to $250 \mathrm{mg} / \mathrm{m}^{2}$ & 6 hours & 1.3 to $2.6 \mu \mathrm{M}$ & 7.8 to 15.6 & $44(44)$ & [150] \\
\hline $\mathrm{AML}^{\mathrm{d}}$ & 125 to $250 \mathrm{mg} / \mathrm{m}^{2}$ & 6 hours & 1.3 to $2.6 \mu \mathrm{M}$ & 7.8 to 15.6 & $41(41)$ & [151] \\
\hline $\mathrm{AML}^{\mathrm{d}}$ & 125 to $250 \mathrm{mg} / \mathrm{m}^{2}$ & 6 hours & 1.3 to $2.6 \mu \mathrm{M}$ & 7.8 to 15.6 & $82(73)$ & [137] \\
\hline AML & 250 to $500 \mathrm{mg} / \mathrm{m}^{2}$ & 6 hours & 2.61 to $5.2 \mu \mathrm{M}$ & 15.66 to 31.2 & $20(0)$ & [137] \\
\hline AML & 270 to $360 \mathrm{mg} / \mathrm{m}^{2} /$ day ti.d. & 4 hours & 4.2 to $5.6 \mu \mathrm{M}$ & 16.8 to 22.4 & $40(30)$ & [109] \\
\hline $\begin{array}{l}\mathrm{AML}, \mathrm{ALL}, \\
\mathrm{CML}\end{array}$ & 300 to $500 \mathrm{mg} / \mathrm{m}^{2} /$ day c. i.v. & $\begin{array}{l}24 \text { to } 120 \\
\text { hours }\end{array}$ & 0.16 to $1.3 \mu \mathrm{M}$ & 3.84 to 156.0 & $26(4)$ & [108] \\
\hline AML, ALL & 37 to 80 mg/kg c.i.v. & $\begin{array}{l}36 \text { to } 60 \\
\text { hours }\end{array}$ & 1.4 to $5.15 \mu \mathrm{M}$ & 50.4 to 309.0 & $37(22)$ & [97] \\
\hline AML,ALL & 0.75 to $80 \mathrm{mg} / \mathrm{kg}$ conti.i.v. & $\begin{array}{l}12 \text { to } 44 \\
\text { hours }\end{array}$ & 0.04 to $15 \mu \mathrm{M}$ & 9.0 to 660.0 & $14(9)$ & [7] \\
\hline
\end{tabular}

${ }^{a}$ in combination with ATRA; ${ }^{b}$ in combination with daunorubicin; ${ }^{c}$ in combination with idarubicin; ${ }^{d}$ in combination with amsacrine. $1 \mu$ M $=228$ ng/ml. 5 -AZA-CdR, 5-aza-2'-deoxycytidine; A, accelerated; ALL, acute lymphocytic leukemia; AML, acute myeloid leukemia; ATRA, all trans retinoic acid; AUC, area under the curve; $\mathrm{B}$, blastic; $\mathrm{C}$, chronic; $\mathrm{CML}$, chronic myeloid leukemia; $\mathrm{CMML}$, chronic myelomonocytic leukemia; $\mathrm{CR}$, complete remission; ORR, overall response rate.

blood concentration of 5-AZA-CdR and the exposure time to the drug in solid tumor studies were suboptimal when compared with the results achieved with higher concentrations in both in vitro and in vivo animal studies. As clearly demonstrated in the mouse model, doses of 5-AZA-CdR must be intensified to realize potent antitumor activity [60].

\section{Correlation of the plasma level of 5-AZA-CdR with chemotherapeutic action}

In vitro colony-forming assays of leukemic cells revealed that there is a significant correlation among the concentration of 5-AZA-CdR, the exposure time, and its anticancer and demethylating effects $[44,59]$. A study on human myeloid, T-cell and B-cell lines, revealed that $10 \mu \mathrm{M}$ 5-AZA$\mathrm{CdR}$ for one hour produced a loss of clonogenicity of these cells lines that was $33 \%, 50 \%$, and $49 \%$, respectively. These observations confirm the S-phase specificity of 5-AZA$\mathrm{CdR}$, that is, only cells in S-phase, but not G1 and G2, are targets of this chemotherapy. During a one-hour treatment approximately $50 \%$ of the cells are present in S phase. With an exposure time of 24 hours, $1 \mu \mathrm{M} 5$-AZA-CdR produced $96 \%,>98 \%$, and $100 \%$ losses of clonogenicity, respectively, for the three leukemic cell lines. These findings indicate the importance of the exposure time to 5-AZA-CdR, which should be long enough to permit the transit of all leukemic cells into S-phase. The doubling time of the cell lines was 20 to 24 hours [117].

The therapeutic and toxic effects of 5-AZA-CdR were investigated in mice with L1210 leukemia. The authors of one study concluded that a treatment duration of 24 hours, giving a 5-AZA-CdR plasma level of around $2 \mu \mathrm{M}$, would be most desirable for maximum cell kill [117]. In

\section{Table 7 Correlation of clinical responses and plasma} concentrations of 5-AZA-CdR in patients with MDS

\begin{tabular}{|c|c|c|c|c|}
\hline $\begin{array}{l}\text { Dose- } \\
\text { schedule }\end{array}$ & $\begin{array}{l}\text { Duration } \\
\text { of } \\
\text { infusion }\end{array}$ & $\begin{array}{l}\text { Estimated } \\
\text { plasma } \\
\text { concentration }\end{array}$ & $\begin{array}{l}\text { Response } \\
\% \text { ORR (\% } \\
\text { CR) }\end{array}$ & References \\
\hline $\begin{array}{l}20 \mathrm{mg} / \mathrm{m}^{2} / \text { day } \\
\text { i.v. q } 5 \mathrm{~d}\end{array}$ & 1hour & $1.25 \mu \mathrm{M}$ & 34 (33) & [99] \\
\hline $\begin{array}{l}10 \mathrm{mg} / \mathrm{m}^{2} / \mathrm{day} \\
\text { i.v. q } 10 \mathrm{~d}\end{array}$ & 1hour & $0.63 \mu \mathrm{M}$ & & \\
\hline $\begin{array}{l}15 \mathrm{mg} / \mathrm{m}^{2} \\
\text { i.v t.i.d. } \times 3 \mathrm{~d}\end{array}$ & 4 hours & $0.23 \mu \mathrm{M}$ & 20(15) & [123] \\
\hline $\begin{array}{l}15 \mathrm{mg} / \mathrm{m}^{2} \\
\text { t.i.d. } \mathrm{q} 3 \mathrm{~d}\end{array}$ & 3 hours & $0.31 \mu \mathrm{M}$ & $17(9)$ & [105] \\
\hline
\end{tabular}

$1 \mu \mathrm{M}=228 \mathrm{ng} / \mathrm{ml}$. 5-AZA-CdR, 5-aza-2'-deoxycytidine; CR, complete remission; MDS, myelodysplastic syndrome; ORR, overall response rate. 
another study on L1210 leukemia, the curative dose of 5-AZA-CdR was estimated to be $20 \mathrm{mg} / \mathrm{kg}$ administered as an 18-hour infusion [60]. The estimated plasma concentration of 5-AZA-CdR for this infusion was approximately $3 \mu \mathrm{M}$.

The antileukemic activity of 5-AZA-CdR was also studied in the Brown Norway rat leukemia model, which is a good model of human AML [4]. A dose-response relationship was observed for 5-AZA-CdR for doses up to $50 \mathrm{mg} / \mathrm{kg}$ (administered every 12 hours $\times 3$ ) in this rat model. This dose of 5-AZA-CdR produced a 100\% increase in survival time. In this rat model of AML, 5-AZA-CdR was more effective than ARA-C (at a dose of $200 \mathrm{mg} / \mathrm{kg}$ per treatment). It is interesting that both 5-AZA-CdR and ARA-C reduced the number of normal hematopoietic stem cells in the bone marrow by $30 \%$ to $40 \%$ at a dose of $50 \mathrm{mg} / \mathrm{kg}$, with no further reduction at higher doses $(250 \mathrm{mg} / \mathrm{kg})$. This is a clear indication that the resting normal hematopoietic stem cells survive intensive doses of S-phase-specific agents (administered over an interval of 24 hours) due to the presence of resting non-proliferating hematopoietic stem cells [4].

Studies of the antineoplastic action of 5-AZA-CdR in mouse models of solid tumors provide some insight into the importance of the dose schedule. The in vivo/in vitro EMT6 tumor model is an excellent tool to study the pharmacodynamics of antineoplastic agents [118]. In this model, EMT6 tumor cells from cell culture are injected subcutaneously (s.c.) into mice, and chemotherapy is administered when the tumor size is approximately 3 to $5 \mathrm{~mm}$. After chemotherapy, the tumor is excised and trypsinized, and single-cell suspensions are plated in Petri dishes. Cell survival after chemotherapy is quantified by comparing the number of colonies to the number with controls. Using this assay, 5-AZA-CdR at a dose of $30 \mathrm{mg} / \mathrm{kg}$ as an 18-hour infusion markedly reduced the proliferative potential of the tumor stem cells [60]. The estimated plasma level of 5-AZA-CdR in this treatment was in the range of $4 \mu \mathrm{M}$. These preclinical results illustrate the importance of using intensive chemotherapy with 5-AZA-CdR to obtain a good antitumor response.

\section{Hematopoietic toxicity of 5-Aza-CdR}

The major side effect of 5-AZA-CdR is myelosuppression. In patients with advanced hematologic malignancies, it is difficult to fully evaluate the hematopoietic toxicity of 5-AZA-CdR due to the presence of a large number of abnormal cells in the bone marrow, which can interfere with recovery after chemotherapy. Tumor patients without the presence of malignant cells in the bone marrow are good candidates for the evaluation of hematopoietic toxicity on 'normal bone marrow'. Patients with lung cancer without prior chemotherapy treated with $660 \mathrm{mg} / \mathrm{m}^{2} 5$-AZA-CdR as an eight-hour infusion exhibited significant recovery of the white blood cell count at approximately day 35 [116].
In patients with advanced acute leukemia, the recovery of the granulocyte count $(>500 / \mu \mathrm{l})$ after an intensive dose of 5-AZA-CdR occurred at about day 45 [97]. This observation suggests that the interval between cycles of 5-AZA-CdR therapy should be six weeks to permit adequate recovery of the granulocyte count. At low doses of 5-AZA-CdR (15 to $20 \mathrm{mg} / \mathrm{m}^{2}$ ), the drug is well tolerated in patients with MDS, and the primary hematological toxicity is transient neutropenia, which is predictable and manageable $[92,111,119,120]$.

In a study of patients with CML, 5-AZA-CdR was administered at a dose of 500 to $1,000 \mathrm{mg} / \mathrm{m}^{2}$ over five days and prolonged neutropenia was the major side effect [121,122]. At doses of 75 to $100 \mathrm{mg} / \mathrm{m}^{2}$ delivered over six hours every 12 hours for 10 doses, the median time to neutrophil recovery above $500 / \mu \mathrm{l}$ was 50 (total dose of $1,000 \mathrm{mg} / \mathrm{m}^{2} /$ cycle) or 45 days (total dose of $750 \mathrm{mg} / \mathrm{m}^{2} /$ cycle), respectively.

\section{Discussion}

5-AZA-CdR is an effective epigenetic drug for the treatment of hematologic malignancies. The clinical efficacy of 5-AZA-CdR is due to its demethylating epigenetic action, which reactivates tumor suppressor genes silenced by DNA methylation. Low-dose 5-AZA-CdR $\left(20 \mathrm{mg} / \mathrm{m}^{2}\right.$ one-hour infusion $\mathrm{x}$ five days or $15 \mathrm{mg} / \mathrm{m}^{2}$ four-hour infusion $\mathrm{q} 8 \mathrm{~h} \times$ three days) can produce CRs in patients with MDS and AML $[99,123]$. These low dose schedules cause less toxicity than intensive doses of 5-AZA-CdR. This is especially important for older patients with a poor performance status who are not good candidates for intensive therapy with 5-AZA-CdR. The interesting responses to low-dose 5-AZA-CdR suggest that leukemic stem cells are very sensitive to low concentrations of $5-\mathrm{AZA}-\mathrm{CdR}$, an indication of the immense chemotherapeutic potential of this drug.

Recent preclinical reports indicate that very low dose 5-AZA-CdR administered frequently (two to three times/week) also has the potential to be an effective form of therapy for cancer. One reason for the failure of cytotoxic chemotherapy is that malignant cells can be resistant to the induction of apoptosis due to a nonfunctional p53 pathway as a result of mutations or deletions [124]. However, the genes that program terminal differentiation in these apoptosis-resistant malignant cells can be silenced by epigenetic mechanisms, such as DNA methylation, and reactivated by non-toxic doses of 5-AZA-CdR. This same treatment maintains the selfrenewal of normal hematopoietic stem cells by preventing repression of stem cell genes by differentiation-inducing stimulus and induces differentiation of AML cells [54]. For these reasons the very low dose 5-AZA-CdR does not produce pronounced granulocytopenia as observed with intense doses of this agent. 
Laboratory studies on AML cells support the use of very low-dose 5-AZA-CdR. 5-AZA-CdR inhibits in vitro proliferation, decreases colony formation and induces myeloid differentiation of p53-null AML cells [125]. These observations were confirmed using fresh AML cells from a patient. The AML cells were transplanted into NSG immunosuppressed mice and treated with a s.c. injection of 5-AZACdR $(0.2 \mathrm{mg} / \mathrm{kg}$ three times/week for two weeks, then once/week). This very low dose 5-AZA-CdR was much more effective in prolongation of the survival time of the leukemic mice than an intense dose of ARA-C $(75 \mathrm{mg} / \mathrm{kg}$ per day intraperitoneally for five days). The proof of principle of the very low-dose 5-AZA-CdR was also confirmed in a clinical trial in MDS patients with high-risk cytogenetics [126]. 5-AZA-CdR 3.5 to $7 \mathrm{mg} / \mathrm{m}^{2}$ administered one to three times/week produced an overall response of $84 \%$ (CR + hematologic improvement + stable disease), which is remarkable. Complete cytogenetic remissions were observed in $50 \%$ of the patients. It will be interesting to see if this non-toxic differentiation therapy with 5-AZA-CdR will be effective in older AML patients who are not candidates for cytotoxic chemotherapy.

One limitation of the low dose 5-AZA-CdR for the treatment of AML or MDS is the problem of eradicating malignant cells in the liver or spleen due to the high activity of cytidine deaminase. Deamination of 5-AZA$\mathrm{CdR}$ can reduce its concentration to sub-therapeutic levels in these organs. The use of an inhibitor of cytidine deaminase, such as tetrahydrouridine, in combination with 5-AZA-CdR has the potential to overcome this problem [127]. The proof of principle of this approach was demonstrated in a murine xenotransplant model of AML where tetrahydrouridine produced a marked enhancement of the antineoplastic activity of 5-AZA-CdR [128]. The combination of these agents merits a high priority for clinical investigation in patients with hematologic malignancies.

Preclinical studies indicate that very low-dose 5-AZA$\mathrm{CdR}$ also has the potential to be an effective treatment for tumors with a favorable epigenetic signature. As an example, human renal carcinoma cells derived from a patient were inoculated s.c. into nude mice followed by treatment with low dose 5 -AZA-CdR $(0.2 \mathrm{mg} / \mathrm{kg}$ s.c. $\times 3 /$ week $)$ [129]. This low dose therapy was very effective in reducing tumor growth and did not produce leukopenia. This low dose 5-AZA-CdR, in combination with tetrahydrouridine to inhibit cytidine deaminase, was also very effective in inhibiting the growth of murine melanoma tumors in mice [130]. The low dose chemotherapy did not produce leukopenia or reduction in body weight. 5-AZA-CdR was also shown to induce differentiation of both human and murine melanoma cell lines.

These observations on very low 5-AZA-CdR therapy of leukemia and tumors were confirmed by Tsai et al.
[131] using a different dose-schedule. These investigators showed that low dose 5-AZA-CdR (72-hour exposure) reduced colony formation of AML cells from patients, but not the normal hematopoietic stem cells colony-forming units-granulocyte macrophage (CFU-GM). The low dose 5-AZA-CdR $(0.1 \mu \mathrm{M}, 72$ hours ex vivo $)$ followed by 7 to 14 days drug-free media was also shown to decrease tumorigenicity in mouse tumor xenografts.

In summary, the very low dose 5-AZA-CdR preclinical studies showed that this type of treatment could produce a loss in the self-renewal potential of cancer stem cells due to the increase in the expression of genes that suppress malignancy. These epigenetic changes are maintained in the target cells after drug removal and accumulate with each low dose treatment until there is a complete loss of cancer stem cell potential. The low dose chemotherapy merits clinical investigation in patients with cancer. The very low dose 5-AZA-CdR may also have the potential to maintain $C R$ in patients with leukemia and arrest malignant progression in patients with solid tumors. For cancer patients with poor performance status the very low dose 5-AZA-CdR therapy may be a good option to improve the quality of life rather than the use of only supportive therapy or no treatment.

Some patients with cancer may not respond or show disease progression on the low dose-schedule 5-AZACdR. This may be due to fact that: a) the cancer may have an epigenetic/genetic signature that is not predisposed to the induction of terminal differentiation by low dose 5-AZA-CdR; b) the target cancer cells may have a low level of deoxycytidine kinase, the enzyme that activates the prodrug, 5-AZA-CdR [132]; c) the cancer cells may be in anatomic sanctuaries that have low penetration of 5-AZA-CdR (for example, CSF, testis, tumors with a limited blood supply [133]). The concentration of 5-AZA$\mathrm{CdR}$ in these sanctuaries is too low to eliminate the cancer stem cells; d) the cancer cells may be in a biochemical sanctuary that contains high levels of cytidine deaminase (for example, liver, spleen); e) drug resistance develops more rapidly after repetitive treatments with low-dose chemotherapy; f) because 5 -AZA-CdR is a cell cyclespecific agent, a one- to four-hour infusion of this agent only targets cancer cells in S-phase, whereas cells in G1 and G2 phases escape the chemotherapeutic action of this analog during short-term treatment. A long interval (12 to 24 hours) between infusions can also permit leukemic stem cells to pass through the S-phase cell cycle without exposure to 5-AZA-CdR and, thus, escape its antileukemic action. This possibility was demonstrated in a preclinical study on leukemia using the $\mathrm{S}$ phase-specific drug ARA-C [134].

One approach to overcome these caveats is to use intensive chemotherapy with 5-AZA-CdR administered as 
a continuous infusion for patients with leukemia. This objective is of high priority and involves determination of the optimal plasma level of 5-AZA-CdR and duration of treatment that can eliminate leukemic stem cells in these sanctuaries. The in vitro data on colony assays of human leukemic cell lines indicate that a concentration of 5 -AZA-CdR in the range of 1 to $2 \mu \mathrm{M}$ for the duration of the cell cycle of the leukemic cells has the ability to completely eliminate their proliferative potential. Another approach is to use 5-AZA-CdR in combination with an inhibitor of cytidine deaminase, such as tetrahydrouridine or zebularine, to target the leukemic cells in the biochemical sanctuaries $[135,136]$. An additional approach is to use 5-AZA-CdR in combination with a biochemical modulator, such as 3-deazauridine, to eliminate drug-resistant leukemic cells due to a deficiency in deoxycytidine kinase [132]. Cancer cells deficient in deoxycytidine kinase are very sensitive to the cytotoxic action of 3-deazauridine [132].

One of the key points concerning intensive-dose therapy with 5 -AZA-CdR is the fact that it produces delayed and prolonged myelosuppression. Several investigators have used intensive-dose 5-AZA-CdR in patients with advanced leukemia and observed that most of these patients with a good performance status recovered from the hematopoietic toxicity. These early studies were performed before the clinical use of granulocyte colony stimulating factors to accelerate the recovery from myelosuppression. Some examples of the dose schedules of intensive-dose 5-AZA-CdR that were used are: total dose of $2,479 \mathrm{mg} / \mathrm{m}^{2}$ as a 60 -hour i.v. infusion; $500 \mathrm{mg} / \mathrm{m}^{2}$ as a 6-hour infusion every 12 hours $\times 5$ days for a total dose of $5,000 \mathrm{mg} / \mathrm{m}^{2}$; and a daily dose of 300 to $500 \mathrm{mg} / \mathrm{m}^{2}$ as a 24 to 120 hour infusion $[97,108,137]$. The estimated plasma level of 5-AZA-CdR in these studies ranged from 1 to $3 \mu \mathrm{M}$. The hematopoietic toxicity produced by intensive doses of 5-Aza-CdR can also be predicted from its comparative pharmacology with the related deoxycytidine analogue, ARA-C. Both 5-AZA-CdR and ARA-C are $\mathrm{S}$-phase-specific agents. They have identical metabolism, and their antineoplastic action is due to their incorporation into DNA, but their molecular mechanisms of action differ. 5-AZA-CdR inhibits DNA methylation, whereas ARA-C potently inhibits DNA replication. Because they target the same cells (proliferating cells in $S$ phase), they should produce a similar pattern of hematopoietic toxicity. Most leukemic patients in CR with a good performance status recover from the hematopoietic toxicity produced by very high-dose ARA-C (up to $6,000 \mathrm{mg} / \mathrm{m}^{2} /$ day for four days; total dose $24,000 \mathrm{mg} / \mathrm{m}^{2}$ ) [138]. These observations provide a rationale for intensive doses of 5-AZA-CdR in the range of $1,000 \mathrm{mg} / \mathrm{m}^{2} /$ day in leukemic patients in CR without encountering unacceptable hematologic toxicity for patients with a good performance status. The recovery from granulocytopenia after $5-\mathrm{AZA}-\mathrm{CdR}$ is approximately two weeks longer than that after ARA-C [97]. This is probably due to the delayed epigenetic action of 5-AZA-CdR on normal hematopoietic stem cells compared with the acute cell kill produced by ARA-C. From this point of view, it is better to use a six-week interval between cycles of 5-AZA-CdR rather than the four-week interval used for ARA-C.

It is a remarkable achievement that current chemotherapy can induce CR in most patients with hematologic malignancies. The major challenge is maintaining the patients in CR. Patients in CR are good candidates for experimental chemotherapy because of their good hematologic status. From an ethical point of view, high-risk leukemic patients with an unfavorable karyotype that predicts a poor outcome are good candidates for intensive therapy with 5-AZA-CdR.

Pharmacokinetic/pharmacodynamic calculations can be used to estimate the optimal dose for 5-AZA-CdR. For the initial studies, we recommend a combination of intensive and low-dose 5-Aza-CdR to treat high-risk patients with leukemia. For the initial intensive phase, 5 -AZA-CdR can be infused at a rate of $30 \mathrm{mg} / \mathrm{m}^{2} /$ hour for days one and two (total dose $1,440 \mathrm{mg} / \mathrm{m}^{2} /$ day). This infusion rate should give a plasma concentration of approximately $2 \mu \mathrm{M}$, shown to be very effective in both in vitro and in vivo animal studies on leukemia. The objective of this intensive therapy of 5 -AZA-CdR is to target the most rapidly proliferating leukemic stem cells and those in anatomic and biochemical sanctuaries. The intensive phase is followed by a low-dose phase where 5-AZA-CdR is administered on days three and four as a short infusion at a dose of $30 \mathrm{mg} / \mathrm{m}^{2} /$ day. The objective of this phase is to target cancer stem cells with a long cell cycle that do not enter the $\mathrm{S}$ phase during the first two days of treatment. Supportive care with granulocyte colony stimulating factor is recommended to shorten the duration of granulocytopenia. The interval between each cycle of therapy should be six weeks to permit adequate recovery from bone marrow toxicity. Modifications of the proposed dose schedule may be required for optimization. In subsequent studies, the low-dose phase of $5-\mathrm{AZA}-\mathrm{CdR}$ can be replaced by histone deacetylase (HDAC) and/or histone methylation inhibitors, which showed a synergistic interaction against leukemic cells in preclinical studies $[139,140]$. It could also be interesting to design a clinical study in AML patients to see the efficacy and safety of decitabine in combination with promising novel tyrosine kinase inhibitors such as quizartinib [141]. Both preclinical and clinical observations indicate that 5-AZA-CdR has tremendous potential for the treatment of hematologic malignancies. The results of this proposed clinical trial on 5-AZA-CdR will be of great interest and will hopefully lead to improved overall survival of patients with advanced leukemia. 
Chemotherapy of solid tumors using 5-AZA-CdR also merits clinical investigation. Most malignancies have a large number of tumor suppressor genes that are silenced by aberrant DNA methylation, providing many interesting targets for 5-AZA-CdR therapy. The preclinical data indicate that all types of tumors are sensitive to 5-AZA-CdR treatment, including low dose therapy. However, the clinical responses to low-dose 5AZA-CdR in solid tumors are reported to be very limited. It should be noted, however, that the estimated plasma levels of 5-AZA-CdR in these trials was too low. In vitro clonogenic assays using an exposure time of 24 hours on tumor cells indicate that low concentrations of 5-AZA-CdR are not very effective. Our preclinical data on chemotherapy of tumors in the mouse model suggest that the plasma level of 5-AZA-CdR should be approximately $3 \mu \mathrm{M}$ for curative therapy [60].

An example of the potential of intensive doses for tumor therapy is the pilot stage III/IV NSCLC study where the patients were administered 5-AZA-CdR $\left(660 \mathrm{mg} / \mathrm{m}^{2}\right.$ as an eight-hour infusion), which produced a plasma concentration in the range of $3 \mu \mathrm{M}$. This study produced some promising results: three patients who survived for 15 months and one patient who survived for seven years [116]. The preclinical data support the possibility of this type of response and predict that an infusion time longer than eight hours should be more effective. One major reason for the failure of tumor chemotherapy is the limited penetration of drugs into tumors [133]. One approach to overcome this problem is to obtain high plasma concentrations of anticancer drugs to enhance their penetration into tumors. This provides a rationale for the use of intensive-dose 5-AZA-CdR for the treatment of solid tumors. S phase-specific drugs can be used at very high doses for a limited duration without unacceptable side effects. Patients with metastatic malignancy and poor prognosis are potentially good candidates for intense chemotherapy with 5-AZA-CdR. As an initial study, we suggest a dose schedule of $60 \mathrm{mg} / \mathrm{m}^{2} /$ hour administered as an 18-hour infusion (total dose of $1,080 \mathrm{mg} / \mathrm{m}^{2}$ ). This dose schedule will give an estimated steady state plasma concentration in the range of $4 \mu \mathrm{M}$. The interval between cycles should be six weeks to permit adequate bone marrow recovery. Patients treated previously with intensive cytotoxic chemotherapy are at risk of severe hematopoietic toxicity and require a minimum of four weeks of recovery before being eligible for intensive 5-AZA-CdR therapy. Patients who do not respond to anticancer agents that do not produce hematopoietic toxicity would also be good candidates for this investigational therapy. Depending on the response, the intensive dose schedules for 5-AZA-CdR may have to be modified for optimization (for example, increase the dose and/or duration of the infusion; use low dose 5-AZA-CdR between cycles of intensive doses). The goal should be to optimize the dose-schedule of 5-AZA-
$\mathrm{CdR}$ to reveal its potential for tumor therapy. It may also be possible to increase the effectiveness of this tumor therapy by using a sequential treatment of 5-AZA-CdR followed by an inhibitor of histone modification $[139,140]$ or with a tyrosine kinase inhibitor [142].

\section{Conclusion}

Epigenetic changes, such as DNA methylation, play a very important role in both leukemogenesis and tumorigenesis. Because these epigenetic changes are very prominent in cancer cells and are reversible, they are potential targets for chemotherapy with 5-AZA-CdR. Pharmacodynamic and pharmacokinetic analysis of 5-AZA-CdR from both preclinical and clinical data can provide insight toward optimizing cancer treatment using this interesting epigenetic agent.

\section{Abbreviations}

5-AZA-CdR: 5-Aza-2'-deoxycytidine; ALL: Acute lymphocytic leukemia; AML: Acute myeloid leukemia; ARA-C: Cytosine arabinoside; BSC: Best supportive care; CFU-S: Colony forming unit in spleen; CML: Chronic myeloid leukemia; CMML: Chronic myelomonocytic leukemia; CpG: Cytosinephosphate-guanine; CR: Complete remission; CSF: Cerebrospinal fluid; D50: 50\% decomposition rates; DGU: N'-3-D-2-deoxyribofuranosyl-3guanylurea; DNMT: DNA methyltransferase; FDA: US Food and Drug Administration; G-CSF: Granulocyte colony stimulating factor; HDAC: Histone deacetylase; HPLC: High performance liquid chromatography; HPLC/MS: High performance liquid chromatography/mass spectrometry; IC50: Half maximal inhibitory concentration; i.p: Intraperitoneal; MDS: Myelodysplastic syndrome; MTD: Maximally tolerated dose; NFDU: N-(formylamidino)-N'- $\beta-D-2-$ deoxyribofuranosylurea; NSCLC: Non-small cell lung cancer; OS: Overall survival; s.c: Subcutaneous.

\section{Competing interests}

The authors declare that they have no competing interests.

\section{Authors' contributions}

All authors contributed to the content. All authors read and approved the final manuscript.

\section{Acknowledgements}

Research support by a grant from Canadian Cancer Society research grant 700795.

Received: 1 October 2012 Accepted: 4 January 2013

Published: 1 February 2013

\section{References}

1. Pliml J, Sorm F: Synthesis of 2'-deoxy-D-ribofuranosyl-5-azacytosine. Coll Czech Chem Commun 1964, 29:2576-2577.

2. Sorm F, Vesely J: Effect of 5-aza-2'-deoxycytidine against leukemic and hemopoietic tissues in AKR mice. Neoplasma 1968, 15:339-343.

3. Momparler RL: Pharmacology of 5-Aza-2'-deoxycytidine (decitabine). Semin Hematol 2005, 42(Suppl 2):S9-16.

4. Richel DJ, Colly LP, Lurvink E, Willemze R: Comparison of the antileukaemic activity of 5 aza-2-deoxycytidine and arabinofuranosyl-cytosine in rats with myelocytic leukaemia. Br J Cancer 1988, 58:730-733.

5. Jones PA, Taylor SM: Cellular differentiation, cytidine analogs and DNA methylation. Cell 1980, 20:85-93.

6. Momparler RL: Pharmacology of 5-aza-2'-deoxycytidine. Antimetab Biochem Biol Med 1979, 57:33-41.

7. Rivard GE, Momparler RL, Demers J, Benoit P, Raymond R, Lin K, Momparler LF: Phase I study on 5-aza-2'-deoxycytidine in children with acute leukemia. Leuk Res 1981, 5:453-462.

8. de Vos D, van Overveld W: Decitabine: a historical review of the development of an epigenetic drug. Ann Hematol 2005, 84(Suppl 1):3-8. 
9. Jabbour E, Issa JP, Garcia-Manero G, Kantarjian H: Evolution of decitabine development: accomplishments, ongoing investigations, and future strategies. Cancer 2008, 112:2341-2351.

10. Saunthararajah $Y$, Hillery CA, Lavelle D, Molokie R, Dorn L, Bressler L, Gavazova S, Chen YH, Hoffman R, DeSimone J: Effects of 5-aza-2'deoxycytidine on fetal hemoglobin levels, red cell adhesion, and hematopoietic differentiation in patients with sickle cell disease. Blood 2003, 102:3865-3870.

11. Issa JP, Garcia-Manero G, Giles FJ, Mannari R, Thomas D, Faderl S, Bayar E, Lyons J, Rosenfeld CS, Cortes J, Kantarjian HM: Phase 1 study of low-dose prolonged exposure schedules of the hypomethylating agent 5-aza-2'deoxycytidine (decitabine) in hematopoietic malignancies. Blood 2004, 103:1635-1640.

12. Jones PA, Baylin SB: The fundamental role of epigenetic events in cancer. Nat Rev Genet 2002, 3:415-428.

13. Toyota M, Issa JP: Epigenetic changes in solid and hematopoietic tumors. Semin Oncol 2005, 32:521-530.

14. Berger SL, Kouzarides T, Shiekhattar R, Shilatifard A: An operational definition of epigenetics. Genes Dev 2009, 23:781-783.

15. Esteller M: Epigenetics in cancer. N Engl J Med 2008, 358:1148-1159.

16. Jones PA, Baylin SB: The epigenomics of cancer. Cell 2007, 128:683-692.

17. Taby R, Issa JP: Cancer epigenetics. CA Cancer J Clin 2010, 60:376-392.

18. Esteller M: Relevance of DNA methylation in the management of cancer. Lancet Oncol 2003, 4:351-358.

19. Sakai T, Toguchida J, Ohtani N, Yandell DW, Rapaport JM, Dryja TP. Allele-specific hypermethylation of the retinoblastoma tumor-suppressor gene. Am J Hum Genet 1991, 48:880-888.

20. Herman JG, Latif F, Weng Y, Lerman MI, Zbar B, Liu S, Samid D, Duan DS, Gnarra JR, Linehan WM, et al: Silencing of the VHL tumor-suppressor gene by DNA methylation in renal carcinoma. Proc Natl Acad Sci U S A 1994, 91:9700-9704

21. Esteller M: Cancer epigenomics: DNA methylomes and histonemodification maps. Nat Rev Genet 2007, 8:286-298.

22. Chiang PK, Gordon RK, Tal J, Zeng GC, Doctor BP, Pardhasaradhi K, McCann PP: S-Adenosylmethionine and methylation. FASEB J 1996, 10:471-480.

23. Okano M, Bell DW, Haber DA, Li E: DNA methyltransferases Dnmt3a and Dnmt3b are essential for de novo methylation and mammalian development. Cell 1999, 99:247-257.

24. Rideout WM 3rd, Coetzee GA, Olumi AF, Jones PA: 5-Methylcytosine as an endogenous mutagen in the human LDL receptor and p53 genes. Science 1990, 249:1288-1290.

25. Ehrlich M, Gama-Sosa MA, Huang LH, Midgett RM, Kuo KC, McCune RA, Gehrke C: Amount and distribution of 5-methylcytosine in human DNA from different types of tissues of cells. Nucleic Acids Res 1982, 10:2709-2721.

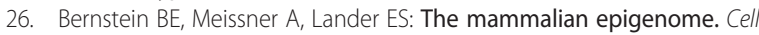
2007, 128:669-681.

27. Reik W: Stability and flexibility of epigenetic gene regulation in mammalian development. Nature 2007, 447:425-432.

28. Hagemann S, Heil O, Lyko F, Brueckner B: Azacytidine and decitabine induce gene-specific and non-random DNA demethylation in human cancer cell lines. PLoS One 2011, 6:e17388.

29. Schneider-Stock R, Diab-Assef M, Rohrbeck A, Foltzer-Jourdainne C, Boltze C, Hartig R, Schonfeld P, Roessner A, Gali-Muhtasib H: 5-Aza-cytidine is a potent inhibitor of DNA methyltransferase $3 a$ and induces apoptosis in HCT-116 colon cancer cells via Gadd45- and p53-dependent mechanisms. J Pharmacol Exp Ther 2005, 312:525-536.

30. Oka M, Meacham AM, Hamazaki T, Rodic N, Chang LJ, Terada N: De novo DNA methyltransferases Dnmt3a and Dnmt3b primarily mediate the cytotoxic effect of 5-aza-2'-deoxycytidine. Oncogene 2005, 24:3091-3099.

31. Ley TJ, Ding L, Walter MJ, McLellan MD, Lamprecht T, Larson DE, Kandoth C, Payton JE, Baty J, Welch J, Harris CC, Lichti CF, Townsend RR, Fulton RS, Dooling DJ, Koboldt DC, Schmidt H, Zhang Q, Osborne JR, Lin L, O'Laughlin M, McMichael JF, Delehaunty KD, McGrath SD, Fulton LA, Magrini VJ, Vickery TL, Hundal J, Cook LL, Conyers JJ, et al: DNMT3A mutations in acute myeloid leukemia. N Engl J Med 2010, 363:2424-2433.

32. Walter MJ, Ding L, Shen D, Shao J, Grillot M, McLellan M, Fulton R, Schmidt H, Kalicki-Veizer J, O'Laughlin M, Kandoth C, Baty J, Westervelt P, DiPersio JF, Mardis ER, Wilson RK, Ley TJ, Graubert TA: Recurrent DNMT3A mutations in patients with myelodysplastic syndromes. Leukemia 2011, 25:1153-1158.

33. Challen GA, Sun D, Jeong M, Luo M, Jelinek J, Berg JS, Bock C, Vasanthakumar A, Gu H, Xi Y, Liang S, Lu Y, Darlington GJ, Meissner A,
Issa JP, Godley LA, Li W, Goodell MA: Dnmt3a is essential for hematopoietic stem cell differentiation. Nat Genet 2011, 44:23-31.

34. Metzeler KH, Walker A, Geyer S, Garzon R, Klisovic RB, Bloomfield CD, Blum W, Marcucci G: DNMT3A mutations and response to the hypomethylating agent decitabine in acute myeloid leukemia. Leukemia 2012, 26:1106-1107.

35. Chabot GG, Rivard GE, Momparler RL: Plasma and cerebrospinal fluid pharmacokinetics of 5-aza-2'-deoxycytidine in rabbits and dogs. Cancer Res 1983, 43:592-597.

36. van Groeningen CJ, Leyva A, O'Brien AM, Gall HE, Pinedo HM: Phase I and pharmacokinetic study of 5-aza-2'-deoxycytidine (NSC 127716) in cancer patients. Cancer Res 1986, 46:4831-4836.

37. Rius M, Keller D, Brom M, Hummel-Eisenbeiss J, Lyko F, Keppler D: Vectorial transport of nucleoside analogs from the apical to the basolateral membrane in double-transfected cells expressing the human concentrative nucleoside transporter hCNT3 and the export pump ABCC4. Drug Metab Dispos 2010, 38:1054-1063.

38. Baldwin SA, Beal PR, Yao SY, King AE, Cass CE, Young JD: The equilibrative nucleoside transporter family, SLC29. Pflugers Arch 2004, 447:735-743.

39. Gray JH, Owen RP, Giacomini KM: The concentrative nucleoside transporter family, SLC28. Pflugers Arch 2004, 447:728-734

40. Pinto A, Attadia V, Fusco A, Ferrara F, Spada OA, Di Fiore PP: 5-Aza-2'deoxycytidine induces terminal differentiation of leukemic blasts from patients with acute myeloid leukemias. Blood 1984, 64:922-929.

41. Bouchard J, Momparler RL: Incorporation of 5-Aza-2'-deoxycytidine-5'triphosphate into DNA. Interactions with mammalian DNA polymerase alpha and DNA methylase. Mol Pharmacol 1983, 24:109-114.

42. Schnekenburger M, Grandjenette C, Ghelfi J, Karius T, Foliguet B, Dicato M, Diederich M: Sustained exposure to the DNA demethylating agent, 2'-deoxy-5-azacytidine, leads to apoptotic cell death in chronic myeloid leukemia by promoting differentiation, senescence, and autophagy. Biochem Pharmacol 2011, 81:364-378.

43. Momparler RL, Derse D: Kinetics of phosphorylation of 5-aza-2'deoxyycytidine by deoxycytidine kinase. Biochem Pharmacol 1979, 28:1443-1444

44. Wilson $\mathrm{VL}$, Jones PA, Momparler RL: Inhibition of DNA methylation in L1210 leukemic cells by 5-aza-2'-deoxycytidine as a possible mechanism of chemotherapeutic action. Cancer Res 1983, 43:3493-3496.

45. Juttermann R, Li E, Jaenisch R: Toxicity of 5-aza-2'-deoxycytidine to mammalian cells is mediated primarily by covalent trapping of DNA methyltransferase rather than DNA demethylation. Proc Natl Acad Sci U S A 1994, 91:11797-11801.

46. Momparler RL, Samson J, Momparler LF, Rivard GE: Cell cycle effects and cellular pharmacology of 5-aza-2'-deoxycytidine. Cancer Chemother Pharmacol 1984, 13:191-194.

47. Chabot GG, Momparler RL: Effects of 5-aza-2'-deoxycytidine on survival and cell cycle progression of L1210 leukemia cells. Leuk Res 1986, 10:533-537.

48. Tobey RA: Effects of cytosine arabinoside, daunomycin, mithramycin, azacytidine, adriamycin, and camptothecin on mammalian cell cycle traverse. Cancer Res 1972, 32:2720-2725.

49. Daskalakis $M$, Nguyen $\Pi$, Nguyen $C$, Guldberg $P$, Kohler G, Wijermans $P$ Jones PA, Lubbert M: Demethylation of a hypermethylated P15/INK4B gene in patients with myelodysplastic syndrome by 5-Aza-2'deoxycytidine (decitabine) treatment. Blood 2002, 100:2957-2964.

50. Momparler RL, Bouchard J, Samson J: Induction of differentiation and inhibition of DNA methylation in HL-60 myeloid leukemic cells by 5-AZA-2'-deoxycytidine. Leuk Res 1985, 9:1361-1366.

51. Katzenellenbogen RA, Baylin SB, Herman JG: Hypermethylation of the DAP-kinase CPG island is a common alteration in B-cell malignancies. Blood 1999, 93:4347-4353.

52. Fulda S, Kufer MU, Meyer E, van Valen F, Dockhorn-Dworniczak B, Debatin KM: Sensitization for death receptor- or drug-induced apoptosis by re-expression of caspase- 8 through demethylation or gene transfer. Oncogene 2001, 20:5865-5877.

53. Attadia V: Effects of 5-aza-2'-deoxycytidine on differentiation and oncogene expression in the human monoblastic leukemia cell line U-937. Leukemia 1993, 7(Suppl 1):9-16.

54. Hu Z, Negrotto S, Gu X, Mahfouz R, Ng KP, Ebrahem Q, Copelan E, Singh H, Maciejewski JP, Saunthararajah Y: Decitabine maintains hematopoietic precursor self-renewal by preventing repression of stem cell genes by a differentiation-inducing stimulus. Mol Cancer Ther 2010, 9:1536-1543. 
55. Pinto A, Maio M, Attadia V, Zappacosta S, Cimino R: Modulation of HLA-DR antigens expression in human myeloid leukaemia cells by cytarabine and 5-aza-2'-deoxycytidine. Lancet 1984, 2:867-868.

56. Pinto A, Zagonel V, Attadia V, Bullian PL, Gattei V, Carbone A, Monfardini S, Colombatti A: 5-Aza-2'-deoxycytidine as a differentiation inducer in acute myeloid leukaemias and myelodysplastic syndromes of the elderly. Bone Marrow Transplant 1989, 4(Suppl 3):28-32.

57. Giralt S, Davis M, O'Brien S, van Besien K, Champlin R, de Vos D, Kantarjian $\mathrm{H}$ : Studies of decitabine with allogeneic progenitor cell transplantation. Leukemia 1997, 11(Suppl 1):S32-34.

58. Momparler RL, Bovenzi V: DNA methylation and cancer. J Cell Physio/ 2000, 183:145-154.

59. Momparler RL, Onetto-Pothier N, Momparler LF: Comparison of antineoplastic activity of cytosine arabinoside and 5-aza-2'-deoxycytidine against human leukemic cells of different phenotype. Leuk Res 1990 14:755-760.

60. Lemaire M, Chabot GG, Raynal NJ, Momparler LF, Hurtubise A, Bernstein ML, Momparler RL: Importance of dose-schedule of 5-aza-2'-deoxycytidine for epigenetic therapy of cancer. BMC Cancer 2008, 8:128.

61. Momparler RL, Momparler LF, Samson J: Comparison of the antileukemic activity of 5-AZA-2'-deoxycytidine, 1-beta-D-arabinofuranosylcytosine and 5-azacytidine against L1210 leukemia. Leuk Res 1984, 8:1043-1049.

62. Saito $Y$, Kanai $Y$, Nakagawa T, Sakamoto M, Saito H, Ishii H, Hirohashi S: Increased protein expression of DNA methyltransferase (DNMT) 1 is significantly correlated with the malignant potential and poor prognosis of human hepatocellular carcinomas. Int J Cancer 2003, 105:527-532.

63. Girault I, Tozlu S, Lidereau R, Bieche I: Expression analysis of DNA methyltransferases 1, 3A, and $3 \mathrm{~B}$ in sporadic breast carcinomas. Clin Cancer Res 2003, 9:4415-4422.

64. Ding WJ, Fang JY, Chen XY, Peng YS: The expression and clinical significance of DNA methyltransferase proteins in human gastric cancer. Dig Dis Sci 2008, 53:2083-2089.

65. Greger V, Passarge E, Hopping W, Messmer E, Horsthemke B: Epigenetic changes may contribute to the formation and spontaneous regression of retinoblastoma. Hum Genet 1989, 83:155-158.

66. Herman JG, Umar A, Polyak K, Graff JR, Ahuja N, Issa JP, Markowitz S, Willson JK, Hamilton SR, Kinzler KW, Kane MF, Kolodner RD, Vogelstein B, Kunkel TA, Baylin SB: Incidence and functional consequences of hMLH1 promoter hypermethylation in colorectal carcinoma. Proc Natl Acad Sci U S A 1998, 95:6870-6875.

67. Kane MF, Loda M, Gaida GM, Lipman J, Mishra R, Goldman H, Jessup JM, Kolodner R: Methylation of the hMLH1 promoter correlates with lack of expression of hMLH1 in sporadic colon tumors and mismatch repairdefective human tumor cell lines. Cancer Res 1997, 57:808-811.

68. Otterson GA, Khleif SN, Chen W, Coxon AB, Kaye FJ: CDKN2 gene silencing in lung cancer by DNA hypermethylation and kinetics of p16INK4 protein induction by 5-aza 2'deoxycytidine. Oncogene 1995, 11:1211-1216.

69. Merlo A, Herman JG, Mao L, Lee DJ, Gabrielson E, Burger PC, Baylin SB, Sidransky D: 5' CpG island methylation is associated with transcriptional silencing of the tumour suppressor p16/CDKN2/MTS1 in human cancers. Nat Med 1995, 1:686-692.

70. Shapiro Gl, Edwards CD, Kobzik L, Godleski J, Richards W, Sugarbaker DJ, Rollins BJ: Reciprocal Rb inactivation and p16INK4 expression in primary lung cancers and cell lines. Cancer Res 1995, 55:505-509.

71. Kratzke RA, Otterson GA, Lincoln CE, Ewing S, Oie H, Geradts J, Kaye FJ: Immunohistochemical analysis of the p16INK4 cyclin-dependent kinase inhibitor in malignant mesothelioma. J Natl Cancer Inst 1995, 87:1870-1875.

72. Costello JF, Berger MS, Huang HS, Cavenee WK: Silencing of p16/CDKN2 expression in human gliomas by methylation and chromatin condensation. Cancer Res 1996, 56:2405-2410

73. Xiao WH, Sanren GW, Zhu JH, Li QW, Kang HR, Wang RL, Song LP, Ye M: Effect of 5-aza-2'-deoxycytidine on immune-associated proteins in exosomes from hepatoma. World J Gastroenterol 2010, 16:2371-2377.

74. Plumb JA, Strathdee G, Sludden J, Kaye SB, Brown R: Reversal of drug resistance in human tumor xenografts by 2'-deoxy-5-azacytidineinduced demethylation of the hMLH1 gene promoter. Cancer Res 2000, 60:6039-6044

75. Strathdee G, Mackean MJ, Illand M, Brown R: A role for methylation of the hMLH1 promoter in loss of hMLH1 expression and drug resistance in ovarian cancer. Oncogene 1999, 18:2335-2341.
76. Gonzalez-Zulueta M, Bender CM, Yang AS, Nguyen T, Beart RW, Van Tornout JM, Jones PA: Methylation of the 5' CpG island of the p16/CDKN2 tumor suppressor gene in normal and transformed human tissues correlates with gene silencing. Cancer Res 1995, 55:4531-4535.

77. Herman JG, Merlo A, Mao L, Lapidus RG, Issa JP, Davidson NE, Sidransky D, Baylin SB: Inactivation of the CDKN2/p16/MTS1 gene is frequently associated with aberrant DNA methylation in all common human cancers. Cancer Res 1995, 55:4525-4530.

78. Dobrovic A, Simpfendorfer D: Methylation of the BRCA1 gene in sporadic breast cancer. Cancer Res 1997, 57:3347-3350.

79. Esteller M, Hamilton SR, Burger PC, Baylin SB, Herman JG: Inactivation of the DNA repair gene O6-methylguanine-DNA methyltransferase by promoter hypermethylation is a common event in primary human neoplasia. Cancer Res 1999, 59:793-797.

80. Soengas MS, Capodieci P, Polsky D, Mora J, Esteller M, Opitz-Araya X, McCombie R, Herman JG, Gerald WL, Lazebnik YA, Cordón-Cardó C, Lowe SW: Inactivation of the apoptosis effector Apaf-1 in malignant melanoma. Nature 2001, 409:207-211.

81. Zhu WG, Dai Z, Ding H, Srinivasan K, Hall J, Duan W, Villalona-Calero MA, Plass C, Otterson GA: Increased expression of unmethylated CDKN2D by 5-aza-2'deoxycytidine in human lung cancer cells. Oncogene 2001, 20:7787-7796.

82. Schmiedel BJ, Arelin V, Gruenebach F, Krusch M, Schmidt SM, Salih HR: Azacytidine impairs NK cell reactivity while decitabine augments NK cell responsiveness toward stimulation. Int J Cancer 2011, 128:2911-2922.

83. Primeau M, Gagnon J, Momparler RL: Synergistic antineoplastic action of DNA methylation inhibitor 5-AZA-2'-deoxycytidine and histone deacetylase inhibitor depsipeptide on human breast carcinoma cells. Int J Cancer 2003, 103:177-184.

84. Numoto K, Yoshida A, Sugihara S, Kunisada T, Morimoto Y, Yoneda Y, Fujita Y, Nishida K, Ouchida M, Ozaki T: Frequent methylation of RASSF1A in synovial sarcoma and the anti-tumor effects of 5-aza-2'-deoxycytidine against synovial sarcoma cell lines. J Cancer Res Clin Oncol 2010, 136:17-25.

85. Caraglia M, Pinto A, Correale P, Zagonel V, Genua G, Leardi A, Pepe S, Bianco AR, Tagliaferri P: 5-Aza-2'-deoxycytidine induces growth inhibition and upregulation of epidermal growth factor receptor on human epithelial cancer cells. Ann Oncol 1994, 5:269-276.

86. Cortvrindt R, Bernheim J, Buyssens N, Roobol K: 5-Azacytidine and 5-aza-2'deoxycytidine behave as different antineoplastic agents in B16 melanoma. Br J Cancer 1987, 56:261-265.

87. Gagnon J, Shaker S, Primeau M, Hurtubise A, Momparler RL: Interaction of 5-aza-2'-deoxycytidine and depsipeptide on antineoplastic activity and activation of 14-3-3sigma, E-cadherin and tissue inhibitor of metalloproteinase 3 expression in human breast carcinoma cells. Anticancer Drugs 2003, 14:193-202.

88. Momparler RL, Goodman J: In vitro cytotoxic and biochemical effects of 5-aza-2'-deoxycytidine. Cancer Res 1977, 37:1636-1639.

89. Brueckner B, Stresemann C, Kuner R, Mund C, Musch T, Meister M, Sultmann $\mathrm{H}$, Lyko F: The human let-7a-3 locus contains an epigenetically regulated microRNA gene with oncogenic function. Cancer Res 2007, 67:1419-1423.

90. Lin KT, Momparler RL, Rivard GE: Sample preparation for the determination of 5-aza-2'-deoxycytidine in plasma by high-performance liquid chromatography. J Chromatog 1985, 345:162-167.

91. Liu Z, Marcucci G, Byrd JC, Grever M, Xiao J, Chan KK: Characterization of decomposition products and preclinical and low dose clinical pharmacokinetics of decitabine (5-aza-2'-deoxycytidine) by a new liquid chromatography/tandem mass spectrometry quantification method. Rapid Commun Mass Spectrom 2006, 20:1117-1126.

92. Cashen AF, Shah AK, Todt L, Fisher N, DiPersio J: Pharmacokinetics of decitabine administered as a 3-h infusion to patients with acute myeloid leukemia (AML) or myelodysplastic syndrome (MDS). Cancer Chemother Pharmacol 2008, 61:759-766.

93. Lin KT, Momparler RL, Rivard GE: High-performance liquid chromatographic analysis of chemical stability of 5-aza-2'-deoxycytidine. J Pharm Sci 1981, 70:1228-1232.

94. Chabot GG, Bouchard J, Momparler RL: Kinetics of deamination of 5-aza-2'-deoxycytidine and cytosine arabinoside by human liver cytidine deaminase and its inhibition by 3-deazauridine, thymidine or uracil arabinoside. Biochem Pharmacol 1983, 32:1327-1328.

95. Ho DH: Distribution of kinase and deaminase of 1-beta-Darabinofuranosylcytosine in tissues of man and mouse. Cancer Res 1973, 33:2816-2820 
96. Lavelle D, Chin J, Vaitkus K, Redkar S, Phiasivongsa P, Tang C, Will R, Hankewych M, Roxas B, Singh M, Saunthararajah Y, Desimone J: Oral decitabine reactivates expression of the methylated gamma-globin gene in Papio anubis. Am J Hematol 2007, 82:981-985.

97. Momparler RL, Rivard GE, Gyger M: Clinical trial on 5-aza-2'-deoxycytidine in patients with acute leukemia. Pharmacol Ther 1985, 30:277-286.

98. Lubbert M: DNA methylation inhibitors in the treatment of leukemias, myelodysplastic syndromes and hemoglobinopathies: clinical results and possible mechanisms of action. Curr Top Microbiol Immunol 2000, 249:135-164.

99. Kantarjian H, Oki Y, Garcia-Manero G, Huang X, O'Brien S, Cortes J, Faderl S, Bueso-Ramos C, Ravandi F, Estrov Z, Ferrajoli A, Wierda W, Shan J, Davis J, Giles F, Saba HI, Issa JP: Results of a randomized study of 3 schedules of low-dose decitabine in higher-risk myelodysplastic syndrome and chronic myelomonocytic leukemia. Blood 2007, 109:52-57.

100. Lubbert M, Minden M: Decitabine in acute myeloid leukemia. Semin Hematol 2005, 42(3 Suppl 2):S38-42.

101. Zagonel V, Lo Re G, Marotta G, Babare R, Sardeo G, Gattei V, De Angelis V, Monfardini S, Pinto A: 5-Aza-2'-deoxycytidine (Decitabine) induces trilineage response in unfavourable myelodysplastic syndromes. Leukemia 1993, 7(Suppl 1):30-35.

102. Wijermans PW, Krulder JW, Huijgens PC, Neve P: Continuous infusion of low-dose 5-Aza-2'-deoxycytidine in elderly patients with high-risk myelodysplastic syndrome. Leukemia 1997, 11:1-5.

103. Egger G, Liang G, Aparicio A, Jones PA: Epigenetics in human disease and prospects for epigenetic therapy. Nature 2004, 429:457-463.

104. Yang AS, Doshi KD, Choi SW, Mason JB, Mannari RK, Gharybian V, Luna R, Rashid A, Shen L, Estecio MR, Kantarjian HM, Garcia-Manero G, Issa JP: DNA methylation changes after 5-aza-2'-deoxycytidine therapy in patients with leukemia. Cancer Res 2006, 66:5495-5503.

105. Kantarjian H, Issa JP, Rosenfeld CS, Bennett JM, Albitar M, DiPersio J, Klimek V, Slack J, de Castro C, Ravandi F, Helmer R 3rd, Shen L, Nimer SD, Leavitt R, Raza A, Saba H: Decitabine improves patient outcomes in myelodysplastic syndromes: results of a phase III randomized study. Cancer 2006, 106:1794-1803.

106. Lubbert M, Suciu S, Baila L, Ruter BH, Platzbecker U, Giagounidis A, Selleslag D, Labar B, Germing U, Salih HR, Beeldens F, Muus P, Pflüger KH, Coens C, Hagemeijer A, Eckart Schaefer H, Ganser A, Aul C, de Witte T, Wijermans PW: Low-dose decitabine versus best supportive care in elderly patients with intermediate- or high-risk myelodysplastic syndrome (MDS) ineligible for intensive chemotherapy: final results of the randomized phase III study of the European Organisation for Research and Treatment of Cancer Leukemia Group and the German MDS Study Group. J Clin Oncol 2011, 29:1987-1996.

107. Borthakur G, Ahdab SE, Ravandi F, Faderl S, Ferrajoli A, Newman B, Issa JP, Kantarjian H: Activity of decitabine in patients with myelodysplastic syndrome previously treated with azacitidine. Leuk Lymphoma 2008, 49:690-695.

108. Debusscher LMJ, Dodion P, Blanc GM, Arrigo C, Zittoun R, Stryckmans P: Phase I-II trial of 5-aza-2 -deoxycytidine in adult patients with acute leukemia. In Proceedings of the workshop on 5-aza-2-deoxycitidine. Haarlem, The Netherlands: PCH Publications; 1990:131-142.

109. Petti MC, Mandelli F, Zagonel V, De Gregoris C, Merola MC, Latagliata R, Gattei V, Fazi P, Monfardini S, Pinto A: Pilot study of 5-aza-2'-deoxycytidine (Decitabine) in the treatment of poor prognosis acute myelogenous leukemia patients: preliminary results. Leukemia 1993, 7(Suppl 1):36-41

110. Cashen AF, Schiller GJ, O'Donnell MR, DiPersio JF: Multicenter, phase II study of decitabine for the first-line treatment of older patients with acute myeloid leukemia. J Clin Oncol 2010, 28:556-561.

111. Plimack ER, Kantarjian HM, Issa JP: Decitabine and its role in the treatment of hematopoietic malignancies. Leuk Lymphoma 2007, 48:1472-1481.

112. Kantarjian HM, Thomas XG, Dmoszynska A, Wierzbowska A, Mazur G, Mayer J, Gau JP, Chou WC, Buckstein R, Cermak J, Kuo CY, Oriol A, Ravandi F, Faderl S, Delaunay J, Lysák D, Minden M, Arthur C: Multicenter, randomized, open-label, phase III trial of decitabine versus patient choice, with physician advice, of either supportive care or low-dose cytarabine for the treatment of older patients with newly diagnosed acute myeloid leukemia. J Clin Oncol 2012, 30:2670-2677.

113. FDA Staff Says Decitabine No Help in AML. http://www.medpagetoday.com/ HematologyOncology/Leukemia/31081.

114. Thibault A, Figg WD, Bergan RC, Lush RM, Myers CE, Tompkins A, Reed E, Samid D: A phase II study of 5-aza-2'deoxycytidine (decitabine) in hormone independent metastatic (D2) prostate cancer. Tumori 1998, 84:87-89.

115. Samlowski WE, Leachman SA, Wade M, Cassidy P, Porter-Gill P, Busby L, Wheeler R, Boucher K, Fitzpatrick F, Jones DA, Karpf AR: Evaluation of a 7-day continuous intravenous infusion of decitabine: inhibition of promoter-specific and global genomic DNA methylation. J Clin Oncol 2005, 23:3897-3905.

116. Momparler RL, Bouffard DY, Momparler LF, Dionne J, Belanger K, Ayoub J: Pilot phase I-II study on 5-aza-2'-deoxycytidine (Decitabine) in patients with metastatic lung cancer. Anticancer Drugs 1997, 8:358-368.

117. Covey JM, Zaharko DS: Comparison of the in vitro cytotoxicity (L1210) of 5-aza-2'-deoxycytidine with its therapeutic and toxic effects in mice. Eur J Cancer Clin Oncol 1985, 21:109-117.

118. Rockwell S: Tumor-cell survival. In Tumor Models In Cancer Research. Totowa, NJ: Humana Press; 2002:617-631.

119. Bryan J, Jabbour E, Prescott H, Garcia-Manero G, Issa JP, Kantarjian H: Current and future management options for myelodysplastic syndromes. Drugs 2010, 70:1381-1394.

120. Atallah E, Kantarjian H, Garcia-Manero G: The role of decitabine in the treatment of myelodysplastic syndromes. Expert Opin Pharmacother 2007, 8:65-73.

121. Kantarjian HM, O'Brien SM, Estey E, Giralt S, Beran M, Rios MB, Keating M, de Vos D, Talpaz M: Decitabine studies in chronic and acute myelogenous leukemia. Leukemia 1997, 11(Suppl 1):S35-36.

122. Kantarjian HM, O'Brien SM, Keating M, Beran M, Estey E, Giralt S, Kornblau S, Rios MB, de Vos D, Talpaz M: Results of decitabine therapy in the accelerated and blastic phases of chronic myelogenous leukemia. Leukemia 1997, 11:1617-1620.

123. Wijermans $P$, Lubbert M, Verhoef $G$, Bosly A, Ravoet C, Andre M, Ferrant A: Low-dose 5-aza-2'-deoxycytidine, a DNA hypomethylating agent, for the treatment of high-risk myelodysplastic syndrome: a multicenter phase II study in elderly patients. J Clin Oncol 2000, 18:956-962.

124. Saunthararajah $Y$, Triozzi $P$, Rini B, Singh A, Radivoyevitch T, Sekeres M, Advani A, Tiu R, Reu F, Kalaycio M, Copelan E, Hsi E, Lichtin A, Bolwell B: p53-Independent, normal stem cell sparing epigenetic differentiation therapy for myeloid and other malignancies. Semin Oncol 2012, 39:97-108.

125. Ng KP, Ebrahem Q, Negrotto S, Mahfouz RZ, Link KA, Hu Z, Gu X, Advani A Kalaycio M, Sobecks R, Sekeres M, Copelan E, Radivoyevitch T, Maciejewski J, Mulloy JC, Saunthararajah Y: p53 independent epigenetic-differentiation treatment in xenotransplant models of acute myeloid leukemia. Leukemia 2011, 25:1739-1750

126. Mahfouz RZ, Rickki E, Juersivich JA, Cooper K, Durkin L, Radivoyevitch T, Tiu RV, Reu FJ, Dean RM, Sobecks R, Kalaycio M, Copelan EA, Advani A, His ED, Sekeres MA, Maciejewski JP, Saunthararajah Y: Non-Cytotoxic differentiation therapy based on mechanism of disease produces complete remission in myelodysplastic syndromes (MDS) with high risk [abstract]. Blood 2012, 120(21):1696.

127. Eliopoulos N, Cournoyer D, Momparler RL: Drug resistance to 5-aza-2'deoxycytidine, 2',2'-difluorodeoxycytidine, and cytosine arabinoside conferred by retroviral-mediated transfer of human cytidine deaminase cDNA into murine cells. Cancer Chemother Pharmacol 1998, 42:373-378.

128. Ebrahem Q, Mahfouz RZ, Ng KP, Saunthararajah Y: High cytidine deaminase expression in the liver provides sanctuary for cancer cells from decitabine treatment effects. Oncotarget 2012, 3:1137-1145.

129. Negrotto S, Hu Z, Alcazar O, Ng KP, Triozzi P, Lindner D, Rini B, Saunthararajah $Y$ : Noncytotoxic differentiation treatment of renal cell cancer. Cancer Res 2011, 71:1431-1441.

130. Alcazar O, Achberger S, Aldrich W, Hu Z, Negrotto S, Saunthararajah Y, Triozzi P: Epigenetic regulation by decitabine of melanoma differentiation in vitro and in vivo. Int J Cancer 2012, 131:18-29.

131. Tsai HC, Li H, Van Neste L, Cai Y, Robert C, Rassool FV, Shin JJ, Harbom KM, Beaty R, Pappou E, Harris J, Yen RW, Ahuja N, Brock MV, Stearns V, Feller-Kopman D, Yarmus LB, Lin YC, Welm AL, Issa JP, Minn I, Matsui W, Jang YY, Sharkis SJ, Baylin SB, Zahnow CA: Transient low doses of DNA-demethylating agents exert durable antitumor effects on hematological and epithelial tumor cells. Cancer Cell 2012, 21:430-446.

132. Raynal NJ, Momparler LF, Rivard GE, Momparler RL: 3-Deazauridine enhances the antileukemic action of 5-aza-2'-deoxycytidine and targets drug-resistance due to deficiency in deoxycytidine kinase. Leuk Res 2011, 35:110-118. 
133. Minchinton Al, Tannock IF: Drug penetration in solid tumours. Nat Rev Cancer 2006, 6:583-592.

134. Leclerc JM, Momparler RL: Effect of the interval between exposures to cytarabine on its cytotoxic action on HL-60 myeloid leukemic cells. Cancer Treat Rep 1984, 68:1143-1148.

135. Lavelle D, Vaitkus K, Ling Y, Ruiz MA, Mahfouz R, Ng KP, Negrotto S, Smith $\mathrm{N}$, Terse P, Engelke KJ, Covey J, Chan KK, Desimone J, Saunthararajah Y: Effects of tetrahydrouridine on pharmacokinetics and pharmacodynamics of oral decitabine. Blood 2012, 119:1240-1247.

136. Lemaire M, Momparler LF, Raynal NJ, Bernstein ML, Momparler RL: Inhibition of cytidine deaminase by zebularine enhances the antineoplastic action of 5-aza-2'-deoxycytidine. Cancer Chemother Pharmacol 2009, 63:411-416.

137. Richel DJ, Colly LP, Kluin-Nelemans JC, Willemze R: The antileukaemic activity of 5-Aza-2 deoxycytidine (Aza-dC) in patients with relapsed and resistant leukaemia. Br J Cancer 1991, 64:144-148.

138. Kern W, Aul C, Maschmeyer G, Schonrock-Nabulsi R, Ludwig WD, Bartholomaus A, Bettelheim P, Wormann B, Buchner T, Hiddemann W: Superiority of high-dose over intermediate-dose cytosine arabinoside in the treatment of patients with high-risk acute myeloid leukemia: results of an age-adjusted prospective randomized comparison. Leukemia 1998, 12:1049-1055.

139. Lemaire M, Momparler LF, Farinha NJ, Bernstein M, Momparler RL: Enhancement of antineoplastic action of 5-aza-2'-deoxycytidine by phenylbutyrate on L1210 leukemic cells. Leuk Lymphoma 2004, 45:147-154.

140. Momparler RL, Idaghdour Y, Marquez VE, Momparler LF: Synergistic antileukemic action of a combination of inhibitors of DNA methylation and histone methylation. Leuk Res 2012, 36:1049-1054.

141. Levis MJ, Perl AE, Dombret $H$, Döhner $H$, Steffen $B$, Rousselot $P$, Martinelli $G$, Estey EH, Burnett AK, Guy G, Trone D, Leo E, Cortes JE: Final results of a phase 2 open-label, monotherapy efficacy and safety study of quizartinib (AC220) in patients with FLT3-ITD positive or negative relapsed/refractory acute myeloid leukemia after second-line chemotherapy or hematopoietic stem cell transplantation [abstract]. Blood 2012, 120(21):673.

142. Pao W, Ladanyi M, Miller VA: Lung cancer oncogenome G: erlotinib in lung cancer. N Engl J Med 2005, 353:1739-1741. author reply.

143. Lubbert M, Ruter BH, Claus R, Schmoor C, Schmid M, Germing U, Kuendgen A, Rethwisch V, Ganser A, Platzbecker U, Galm O, Brugger W, Heil G, Hackanson B, Deschler B, Döhner K, Hagemeijer A, Wijermans PW, Döhner $\mathrm{H}$ : A multicenter phase II trial of decitabine as first-line treatment for older patients with acute myeloid leukemia judged unfit for induction chemotherapy. Haematologica 2012, 97:393-401.

144. Blum W, Garzon R, Klisovic RB, Schwind S, Walker A, Geyer S, Liu S, Havelange $V$, Becker $H$, Schaaf $L$, et al: Clinical response and miR-29b predictive significance in older AML patients treated with a 10-day schedule of decitabine. Proc Natl Acad Sci U S A 2010, 107:7473-7478.

145. Wijermans PW, Lubbert $M$, Verhoef $G$, Klimek V, Bosly A: An epigenetic approach to the treatment of advanced MDS; the experience with the DNA demethylating agent 5-aza-2'-deoxycytidine (decitabine) in 177 patients. Ann Hematol 2005, 84(Suppl 1):9-17.

146. Wijermans PW, Ruter B, Baer MR, Slack JL, Saba HI, Lubbert M: Efficacy of decitabine in the treatment of patients with chronic myelomonocytic leukemia (CMML). Leuk Res 2008, 32:587-591.

147. Cashen AF, Devine H, DiPersio J: Second complete remission in an elderly patient with acute myeloid leukemia retreated with decitabine. Am J Hematol 2006, 81:543-545.

148. Kantarjian HM, O'Brien S, Cortes J, Giles FJ, Faderl S, Issa JP, Garcia-Manero G, Rios MB, Shan J, Andreeff M, Keating M, Talpaz M: Results of decitabine (5-aza-2'deoxycytidine) therapy in 130 patients with chronic myelogenous leukemia. Cancer 2003, 98:522-528.

149. Schwartsmann G, Fernandes MS, Schaan MD, Moschen M, Gerhardt LM, Di Leone L, Loitzembauer B, Kalakun L: Decitabine (5-Aza-2'-deoxycytidine; DAC) plus daunorubicin as a first line treatment in patients with acute myeloid leukemia: preliminary observations. Leukemia 1997, 11(Suppl 1):S28-31.

150. Willemze R, Archimbaud E, Muus P: Preliminary results with 5-aza-2'deoxycytidine (DAC)-containing chemotherapy in patients with relapsed or refractory acute leukemia. The EORTC Leukemia Cooperative Group. Leukemia 1993, 1(7 Suppl):49-50.
151. Willemze $R$, Suciu $S$, Archimbaud E, Muus $P$, Stryckmans $P$, Louwagie EA, Berneman Z, Tjean M, Wijermans P, Dohner H, Jehn U, Labar B, Jaksic B, Dardenne $M$, Zittoun R: A randomized phase II study on the effects of 5-Aza-2'-deoxycytidine combined with either amsacrine or idarubicin in patients with relapsed acute leukemia: an EORTC Leukemia Cooperative Group phase II study (06893). Leukemia 1997, 11(Suppl 1):S24-27.

doi:10.1186/1868-7083-5-3

Cite this article as: Karahoca and Momparler: Pharmacokinetic and pharmacodynamic analysis of 5-aza-2'-deoxycytidine (decitabine) in the design of its dose-schedule for cancer therapy. Clinical Epigenetics 2013 $5: 3$.

\section{Submit your next manuscript to BioMed Central and take full advantage of:}

- Convenient online submission

- Thorough peer review

- No space constraints or color figure charges

- Immediate publication on acceptance

- Inclusion in PubMed, CAS, Scopus and Google Scholar

- Research which is freely available for redistribution 